JOÃO GILBERTO BELVEL FERNANDES JÚNIOR

A EFICÁCIA DAS RESTRIÇÕES URBANÍSTICAS CONVENCIONAIS DE LOTEAMENTOS EM FACE DA FUNÇÃO SOCIAL DA PROPRIEDADE URBANA

\author{
Dissertação de Mestrado
}

Orientador: Prof. Dr. Alcides Tomasetti Júnior

UNIVERSIDADE DE SÃO PAULO

FACULDADE DE DIREITO

SÃO PAULO - SP

2020 

JOÃO GILBERTO BELVEL FERNANDES JÚNIOR

\title{
A EFICÁCIA DAS RESTRIÇÕES URBANÍSTICAS CONVENCIONAIS DE LOTEAMENTOS EM FACE DA FUNÇÃO SOCIAL DA PROPRIEDADE URBANA
}

\begin{abstract}
Dissertação apresentada a Banca Examinadora do Programa de Pós-Graduação em Direito, da Faculdade de Direito da Universidade de São Paulo, como exigência parcial para obtenção do título de Mestre em Direito, na área de concentração de Direito Civil, sob a orientação do Prof. Dr. Alcides Tomasetti Júnior.
\end{abstract}

UNIVERSIDADE DE SÃO PAULO

FACULDADE DE DIREITO

SÃO PAULO - SP 
Catalogação da Publicação Serviço de Biblioteca e Documentação Faculdade de Direito da Universidade de São Paulo

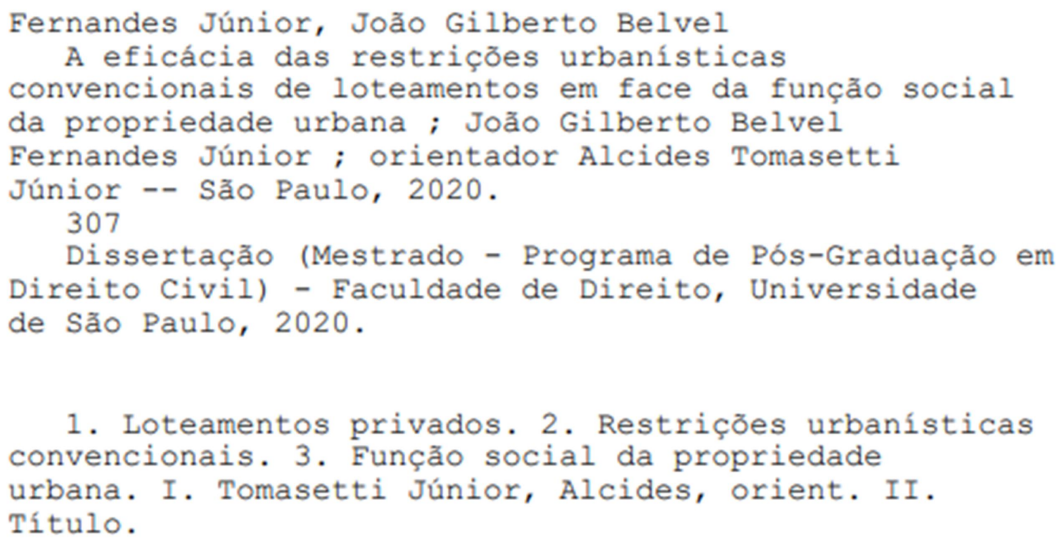

1. Loteamentos privados. 2. Restriçöes urbanísticas convencionais. 3. Função social da propriedade urbana. I. Tomasetti Júnior, Alcides, orient. II. Título. 


\section{AGRADECIMENTOS}

Duas mãos, e uma pessoa, redigiram esta dissertação. Mas, para parafrasear Deleuze \& Guatarri (2011, v.1, p. 17), nas multiplicidades que somos todos, eu já era muita gente. Porque havia muita gente comigo.

Por ser quem me tornei e por ter podido trilhar o caminho que trilho, agradeço primeiro à minha família, nominalmente: João Gilberto Belvel Fernandes, Andréa dos Santos Belvel Fernandes e Andressa Belvel Fernandes. É principalmente por esses nomes, mas também pelos nomes de todos aqueles que amo, sem dúvida, que a maior e a melhor parte de mim atende.

Aos meus professores e mestres, os que estão e são, e os que já se foram, mas continuam sendo, eu os agradeço igualmente, por tudo o que me ensinaram: coisas que não se perdem, e que, se não nos mudam, é porque não as apreendemos de verdade. Pela oportunidade de realizar esta pesquisa, todavia, agradeço especialmente ao Prof. Alcides Tomasetti Júnior, meu orientador, e aos Profs. Luciano de Camargo Penteado (in memoriam) e Nuno Manuel Morgadinho dos Santos Coelho, que me apresentaram ao tema deste trabalho.

Muitos amigos se dispuseram a discutir este texto comigo. Seria difícil enumerá-los, porque os números são traiçoeiros - eles supõem a unidade. Nas pessoas de Bárbara Ferreira Lima, Gabriel Hardt Gomes e Hugo Rezende Henriques, que demonstraram para comigo gentileza e paciência inesgotáveis no caminho que passa por essa dissertação, eu agradeço a todos. 

João Gilberto Belvel Fernandes Júnior. A eficácia das restrições urbanísticas convencionais de loteamentos em face da função social da propriedade urbana. 20 de janeiro de 2020. 308 pp. Mestrado - Faculdade de Direito, Universidade de São Paulo, São Paulo, 2020.

RESUMO: Esta dissertação toma o caso da jurisprudência do Tribunal de Justiça de São Paulo sobre a eficácia das restrições urbanísticas convencionais de loteamentos como laboratório a partir do qual averigua as possibilidades de autonomia epistemológica e normativa do Direito Civil, assim como as suas potencialidades políticas no processo democrático. Foram analisadas, quantitativa e qualitativamente, todas as decisões judiciais produzidas pela Corte sobre o assunto entre os anos de 2006 e 2016. Os resultados da análise foram codificados em três modelos típicos de decisão os quais, durante o período, orientaram os julgadores do TJ-SP. Mostrou-se que estes modelos convivem na jurisprudência do Tribunal em equilíbrio dinâmico, o que revela os contornos de um debate político e jurídico que ainda está em andamento e que se itera em múltiplas arenas de disputa agonística, determinando muitas vezes os contornos dos regulamentos sócio-espaciais concretos das cidades paulistas e de seus bairros. O caso dos "bairros-jardim" da capital de São Paulo, sobre os quais foi feita uma análise genealógica, é utilizado como parâmetro a partir do qual estas arenas foram mapeadas $e$ as relações entre elas foram estabelecidas. Neste debate, o Direito Privado, e especialmente o Direito Civil, surge como a disciplina capaz de traduzir os interesses pertinentes aos diferentes modos de vida urbanos para a gramática e para a linguagem do Direito, confrontando-se com o Direito Público estatal de maneira dialógica, através da oposição entre aquilo a que se chamou de um binômio entre "dogmáticas ascendentes" e "dogmáticas descendentes". Conclui-se que o Direito Civil, desde que a sua autonomia seja garantida e que ele se apegue à codificação das práticas locais e cotidianas e suas simbolizações, atua como um dos instrumentos de consensualização do processo democrático.

PALAVRAS-CHAVE: loteamentos privados; restrições urbanísticas convencionais; função social da propriedade urbana. 

João Gilberto Belvel Fernandes Júnior. The efficacy of conventional urbanistic restrictions for allotments in the face of the principle of the social function of the urban property. 20 of January of 2020. 308 pgs. Master - Faculty of Law, University of São Paulo, São Paulo, 2020.

\begin{abstract}
This thesis has the jurisprudence emanated from the "Tribunal de Justiça de São Paulo" (TJ-SP) on the subject of the efficacy of conventional urbanistic restrictions for allotments as a laboratory from which it investigates the possibilities of epistemological and normative autonomy of the Civil Law field, as well as its political potentialities in the democratic process. We analyzed, quantitively and qualitatively, all decisions from the Court on that subject between years of 2006 and 2016. Analysis results were categorized into three models of typical decisions which, during the period, guided the TJ-SP judges. We showed that these models coexist in the Tribunal's jurisprudence in a dynamic equilibrium which reveals the shaping of a political and juridical debate that often determines the concrete design of socio-spatial regulations in São Paulo's municipalities and neighborhoods. The cases of São Paulo's city "garden-neighborhoods", about which we carried a genealogic analysis, is used as a parameter from which these arenas were mapped and their relations established. In this debate, the field of Private Law, and especially that of Civil Law, emerges as a discipline capable of translating the pertinent interests to different urban life styles to law's grammar and language, confronting itself with the State's Public Law field in a dialogical manner, through the opposition between that which we named a binomial between an "ascending dogmatic" and a "descending dogmatic". We concluded that the Civil Law field, as long as its autonomy is guaranteed and if it focuses on codifying local and daily practices and their symbolizations, acts as one of the consensualizing instruments in the democratic process.
\end{abstract}

KEYWORDS: private allotments; conventional urbanistic restrictions, social function of the urban property. 



\section{Sumário}

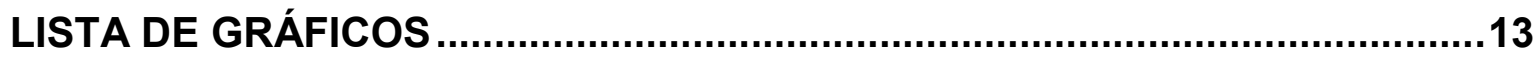

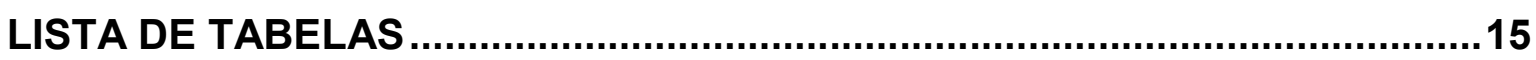

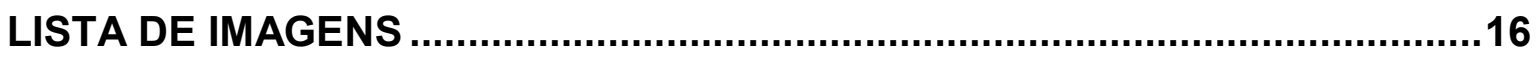

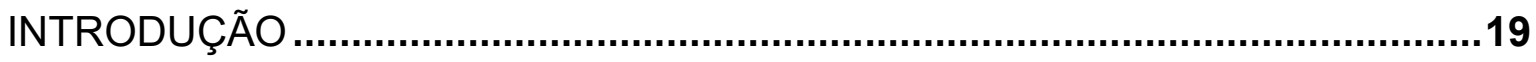

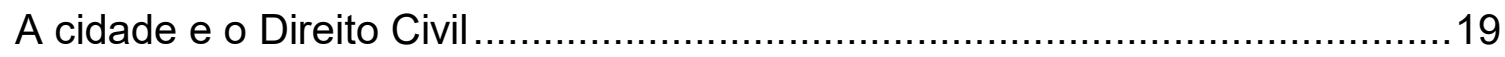

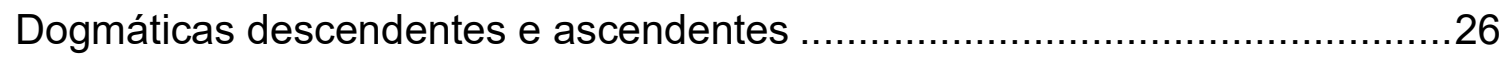

O caso das restrições urbanísticas convencionais .........................................28

CAPÍTULO 1 - O LOTEAMENTO, O BAIRRO E A CIDADE................................33

1. Os modos de vida urbanos, os sentidos do bairro e o direito à cidade ........34

2. O caso dos "bairros-jardim" paulistanos .......................................................4

3. A cidade entre o lugar e o objeto do mercado.............................................

CAPÍTULO 2 - O LOTEAMENTO, AS RESTRIÇÕES URBANÍSTICAS CONVENCIONAIS E O DIREITO POSITIVO …..................................................79

1. O loteamento enquanto instrumento de parcelamento do solo urbano ........80

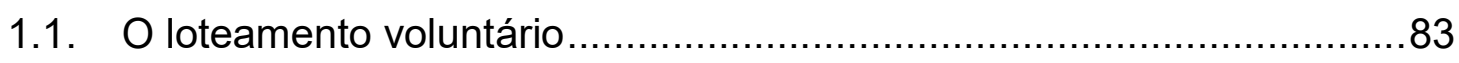

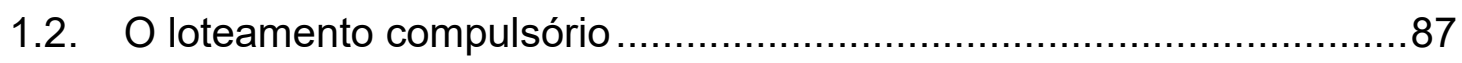

2. Do planejamento do loteamento ao registro do memorial descritivo: o

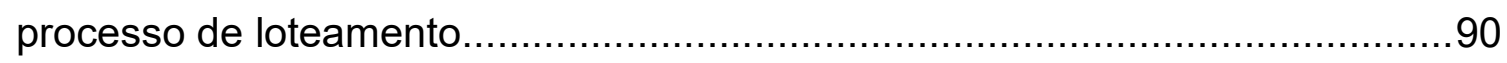

3. As restrições urbanísticas convencionais .....................................................99

3.1. Restrições urbanísticas convencionais socialmente típicas e suas funções urbanísticas e econômicas ............................................................100

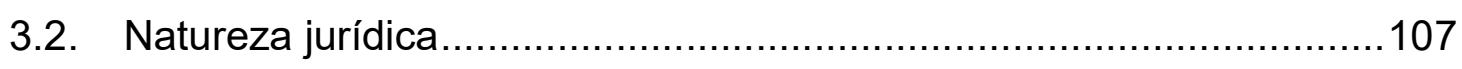

3.3. A publicidade registral em face dos contratos de alienação dos lotes: oponibilidade e vinculatividade.

CAPÍTULO 3 - AS RESTRIÇÕES URBANÍSTICAS CONVENCIONAIS NA JURISPRUDÊNCIA: AS JUSTIFICATIVAS JUDICIAIS PARA A

INEFICACIZAÇÃO A POSTERIORI DAS RESTRIÇÕES 
1. Compendiando a experiência: o método, os perfis e os tipos de casos ... 123

2. Os modelos dogmáticos de decisão 150

2.1. A "solução Hely Lopes Meirelles", ou da prevalência do Direito Público sobre o Direito Privado. 151

2.2. A "solução Antônio Junqueira de Azevedo", ou da perda de sentido das restrições urbanísticas convencionais 164

2.3. A "solução Herman Benjamin", ou da prevalência da norma com maior valor axiológico.

CAPÍTULO 4 - A FUNÇÃO SOCIAL DA PROPRIEDADE E AS RESTRIÇÕES URBANÍSTICAS CONVENCIONAIS: ENTRE AS MULTIPLICIDADES, A SEGURANÇA JURÍDICA E O PROCESSO DEMOCRÁTICO

1. A multiplicidade de critérios decisórios e de modos de vida em face da segurança jurídica 198

2. Ensaiando uma dogmática ascendente para a função social da propriedade 215

3. A autonomia do Direito Civil e o processo democrático: o caso das restrições urbanísticas convencionais 232

CONCLUSÃO 249

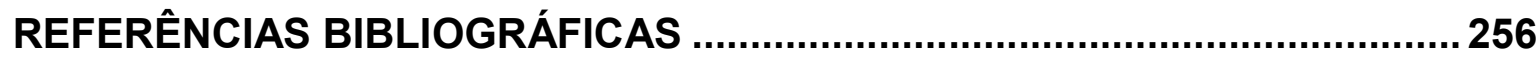

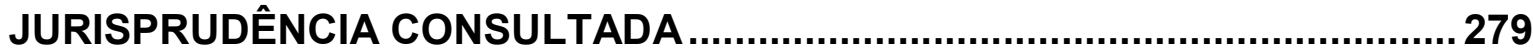

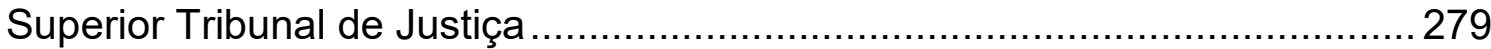

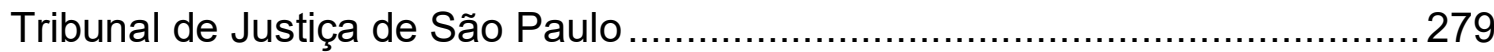

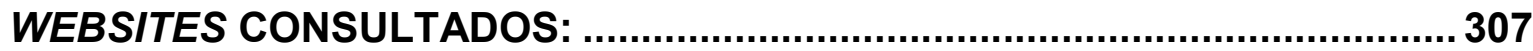




\section{LISTA DE GRÁFICOS}

Gráfico 1: Decisões aproveitadas e descartadas, dentre aquelas proferidas pelo TJ-SP $(n=330)$

Gráfico 2: Distribuição dos casos selecionados do TJ-SP de acordo com a natureza do feito

Gráfico 3: Distribuição dos casos analisados do TJ-SP por porte do Município de origem

Gráfico 4: Distribuição das taxas médias de casos por categoria de Município e por ano (de 2006 a 2016)

Gráfico 5: Distribuição dos casos analisados em zonas zetropolitanas e nãometropolitanas

Gráfico 6: Distribuição dos casos analisados do TJ-SP por local de origem

Gráfico 7: Distribuição dos casos analisados do TJ-SP por local e porte da cidade de origem

Gráfico 8: Distribuição dos casos analisados por Seção do TJ-SP

Gráfico 9: Distribuição dos casos analisados por ano e por Seção do TJ-SP

Gráfico 10: Distribuição, em números absolutos, dos julgados do TJ-SP por tipo de caso e por ano

Gráfico 11: Distribuição, em números absolutos, dos julgados da Seção de Direito Privado por tipo de caso e por ano

Gráfico 12: Distribuição, em números absolutos dos julgados da Seção de Direito Público por tipo de caso e por ano

Gráfico 13: Decisões dos casos de confronto entre R.U.C. e lei superveniente no TJ-SP 
Gráfico 14: Decisões dos casos de confronto entre R.U.C. e lei superveniente, no TJ-SP, por ano

Gráfico 15: Decisões dos casos de confronto entre R.U.C. e lei superveniente, distribuídas nas Seções do TJ-SP

Gráfico 16: Distribuição dos casos de confronto entre R.U.C. e lei superveniente de acordo com a natureza do feito

Gráfico 17: Decisões dos casos de confronto entre R.U.C. e ato do Poder Executivo no TJ-SP

Gráfico 18: Decisões dos casos de confronto entre R.U.C. e ato do Poder Executivo no TJ-SP, por ano

Gráfico 19: "Boxplot" da distribuição das decisões que dão prevalência aos atos do Poder Executivo sobre as R.U.C.

Gráfico 20: Decisões dos casos de confronto entre R.U.C. e atos do Poder Executivo nas Seções do TJ-SP

Gráfico 21: Distribuição dos casos de confronto entre R.U.C. e ato do Poder Executivo de acordo com sua decisão e com a natureza do feito

Gráfico 22: Decisões dos casos de confronto entre R.U.C. e ato do Poder Executivo no TJ-SP (retificado da atipicidade de 2015)

Gráfico 23: Casos de perda de sentido das R.U.C. distribuídos nas Seções do TJ-SP

Grafico 24: Atução proporcional média de sujeitos típicos como parte dos processos cujas decisões foram analisadas $(n=152)$

Gráfico 25: Atuação proporcional de sujeitos típicos como partes dos processos cujas decisões foram analisadas, calculada por ano $(n=152)$ 


\section{LISTA DE TABELAS}

Tabela 1: Vantagens e desvantagens comparativas entre a cidade, o campo e a cidade-campo tal como concebidos por Ebenezer Howard

Tabela 2: Evolução demográfica da cidade de São Paulo de 1900 a 2000

Tabela 3: Evolução da parte relativa dos aglomerados urbanos (cidades e vilas) com mais de 20 mil habitantes na população total brasileira

Tabela 4: Quadro-resumo das categorias socialmente típicas de restrições urbanísticas convencionais

Tabela 5: Distribuição dos julgados selecionados por Tribunal de origem

Tabela 6: Taxa média de casos por porte de Município e por ano

Tabela 7: Taxa média de casos por pertencimento ou do Município a zonas metropolitanas e por ano

Tabela 8: Taxa média de casos por localização e por ano

Tabela 9: Critérios dos modelos decisórios e sua frequência no período de 2006 a 2016

Tabela 10: As concepções de "cidade", de "Direito" e da "relação entre a cidade e o Direito" dos modelos decisórios

Tabela 11: As questões de moralidade política e de fidelidade no caso dos "bairros-jardim" de São Paulo em função dos modelos decisórios 


\section{LISTA DE IMAGENS}

Imagem 1: Diagrama n. 01 - "Os Três Ímãs".

Imagem 2: Diagrama n. 02 - "Cidade-jardim"

Imagem 3: Diagrama n. 03 - "Cidade-jardim: centro e distrito"

Imagem 4: "Diagrama n. 07" - "Cidade social"

Imagem 5: "Hampstead Garden Suburb: Plan"

Imagem 6: Projeto do Jardim América elaborado por Barry Parker

Imagem 7: Projeto do Pacaembu, finalizado por Barry Parker (com edição do autor)

Imagem 8: Anúncio publicitário da Cia. City

Imagem 9: Anúncio publicitário da Cia. City em O Estado de São Paulo, em 1929

Imagem 10: Anúncio publicitário da Cia. City publicado na Revista Architectura e Construções, em 1930

Imagem 11: Anúncio da Cia. City publicado em O Estado de S. Paulo, em 1929

Imagem 12: Projeto do condomínio "Village Homes", desenhado por Michael Corbett

Imagem 13: Mapa do zoneamento no Jardim América e seus entornos de acordo com a Lei municipal n. 16.402/16, do Município de São Paulo 


\section{INTRODUÇÃO}

\section{A cidade e o Direito Civil}

A "cidade" é um desafio posto à dogmática do Direito Civil.

E, no entanto, a "cidade" só cresce, e o mesmo processo de urbanização que a alimenta desterritorializa os modos de vida tradicionais (Deleuze \& Guatarri, 2004, p. 143 e ss. $)^{1}$, diluindo as relações intersubjetivas que se formam segundo as semelhanças de uma "solidariedade mecânica" (Durkheim, 1999, passim), e reterritorializa os sujeitos em estratos diversos, determinados segundo uma complexificação crescente da divisão social do trabalho que faz se confrontarem no espaço urbano - onde ocorrem todos os mais imprevisíveis encontros (Pétonnet, 2008) - uma miríade de desigualdades e diferenças.

Diante disso, o tempo da moeda e o ritmo do tráfico apressam as reações analíticas e institucionais. De um lado, são analisadas apenas parcialmente as relações que figuram nas ruas e nos mercados: da "socialidade abstrata" travada pelo indivíduo blasé, o qual se isola em si mesmo para preservar o seu espírito (Simmel, 2005) num estoicismo forçado que funda "não-lugares" urbanos (Augé, 2005, p. 65 e ss.), até a "consumeirização da vida" (Bauman, 2008, p. 8 e ss.) enfrentada pelo homo oeconomicus, que é submetido à espetacularização, à fungibilidade e à fugacidade de todas as coisas, perdem-se de vista as "socialidades alargadas" criadas no "fazer cidade" (Agier, 2015, p. 19 e ss.) e - o que é mais grave - o próprio substrato de diversidade que embasa a experiência urbana contemporânea. De outro lado, a tentativa institucional de dar uma resposta à imprevisibilidade, à incerteza e, quiçá, à insegurança (Bauman, 2005, passim) destes (sempre) novos fluxos e eventos, faz com que o Direito, enquanto

\footnotetext{
${ }^{1}$ Neste sentido: "O território pode se desterritorializar, isto é, abrir-se, engajar-se em linhas de fuga e até sair do seu curso e se destruir. A espécie humana está mergulhada num imenso movimento de desterritorialização, no sentido de que seus territórios 'originais' se desfazem ininterruptamente com a divisão social do trabalho, com a ação dos deuses universais que ultrapassam os quadros da tribo e da etnia, com os sistemas maquínicos que a levam a atravessar cada vez mais rapidamente as estratificações materiais e mentais" (Guatarri \& Rolnik, 1996, p. 323). O conceito pode ser entendido como a relação de pertinência entre os sujeitos e uma região social à qual corresponde um código que lhe é próprio (Deleuze \& Parnet, 1998, p. 104 e ss.).
} 
instrumento social, reduza a si mesmo, no mover-se teleológico da ética ${ }^{2}$ à pura administração de conflitos, a um dos mecanismos do "Poder Administrativo" e dos sistemas que "colonizam o mundo da vida" (Habermas, 1997, v. II, p. 57-119) a fim de Ihe atribuir alguma (ou seja, uma única) ordem (predeterminada).

Com estas tendências em jogo, não é de se espantar, dada a ortodoxia da própria disciplina (Bourdieu \& Eagleton, 1996; Bourdieu, 1989, p. 249), o movimento, tão normal quanto evidente, segundo o qual se tenta, com a técnica do Direito Civil e com suas categorias já há muito consagradas (como a "pessoa", o "domínio", o "negócio jurídico", o “contrato", a "família”, a "responsabilidade" etc.) capturar a realidade (Deleuze \& Guatarri, 1997, v.5, p. 97 e ss.), de cima para baixo (ou seja, em consonância com o modus operandi mesmo de um "Poder Administrativo"), subsumindo-a a modelos que, por já não darem conta da pujante diversidade e dos presentes confrontos, tem a sua legitimidade normativa questionada: a que tipo de "pessoa" o Direito Civil se refere?; qual a forma de vida que ele supõe?; de que relações econômicas e sociais ele dá conta?

De certo modo, é à própria ideia de "codificação", entrelaçada tão intrincadamente, no projeto da modernidade (Bourdieu, 1986; Siebeneichler Andrare, 1997, passim; Savigny, 1946, passim) e no desenvolvimento do Direito Civil, que a "cidade" resiste: os habitus (Bourdieu, 2007-b, p. 337 e ss.), os modos de ser, de sentir, de perceber, de agir e de interagir no ambiente (Ingold, 2000, p. 13-26) urbano parecem já não poder encontrar representatividade em fórmulas estanques e pré-definidas - e muito menos naquelas acusadas de serem datadas e/ou parciais.

Daí ser, a "cidade", também um desafio à autonomia do Direito Civil.

\footnotetext{
${ }^{2}$ Neste sentido, conclama Gustav Radbruch (1997, p. 124-125) que ao lado da "justiça", também o direito perseguiria o "bem", valor ético último. Nas suas palavras: "Note-se que, quando formulamos o problema de fim do direito, não nos referimos aos fins empíricos que aqui ou além podem ter provocado o aparecimento deste ou daquele direito positivo, mas sim à meta-empírica de fim, à luz da qual (sub specie æterni) o direito terá de ser apreciado. A resposta a esta pergunta, porém, só poderá ser dada depois de sabermos qual dos valores, ao lado do da justiça daqueles a que deve atribuir-se, assim como a esta, uma validade absoluta - o direito é chamado a servir. Podemos limitar-nos a apontar aqui, mais uma vez, para o tradicional tríptico de todos os valores últimos que já conhecemos - o dos valores éticos, lógicos e estéticos, do bem, da verdade e do belo - pois que imediatamente se reconhecerá que o direito só pode ser chamado a servir um destes valores e, nomeadamente, o valor ético do Bem".
} 
"O proprietário tem a faculdade de usar, gozar e dispor da coisa, e o direito de reavê-la do poder de quem quer que injustamente a possua ou detenha" - é o que diz, sobre o "domínio", o caput do art. 1228 do Código Civil, enunciando o conteúdo da situação jurídica real de propriedade, a fim de determinar um modelo normativo de relação entre um sujeito de direitos e todos os demais membros de uma comunidade política. Tratando-se, o "domínio", de um dos objetos centrais de regulação pelo Direito Civil, a dogmática já destrinçou os significados de cada um dos termos deste enunciado, elencando também cada possibilidade normativa que as relações sintáticas de seu conjunto são capazes de gerar.

$\mathrm{E}$, no entanto, em meio ao tecido urbano, já não se acha nada mais como o "domínio" do art. 1228, caput do Código Civil. O proprietário de um imóvel urbano, por exemplo, não pode "usar" e "gozar" da coisa como bem Ihe aprouver, e as limitações que ele encontra no exercício dessas faculdades não estão todas definidas a priori pelo Código. O "uso" e o "gozo", neste dispositivo, são abstrações. Na prática, o proprietário não poderá, no mais das vezes, realizar toda e qualquer atividade que queira em um imóvel, por exemplo. A depender do zoneamento urbano do Município, naquele imóvel, o "uso" e o "gozo" abstratos poderão se resumir à moradia; ou à moradia e ao desempenho de uma atividade econômica, mas apenas relacionada ao pequeno comércio ou a profissões liberais. Por outro lado, entendido o "direito de construir" como um dos significados possíveis da faculdade abstrata de "usar", poderá o proprietário ser constrangido a manter uma parte de seu terreno reservado a área verde ou a faixa non aedificandi, em virtude do Código de Obras municipal ou de outras restrições que porventura incidirem sobre a região. Ele poderá ter de tolerar servidões administrativas ou privadas que restrinjam seu "uso" e seu "gozo" sobre o bem a que faz jus, deverá pagar impostos sobre a propriedade, que variarão segundo o bairro e as condições urbanas do entorno, e mais uma série de deveres que lhe surgirão na constância da titularidade da situação jurídica de propriedade. Até mesmo ao seu exercício abstensivo serão impostos limites, como aqueles que o sancionam com o Imposto Predial e Territorial Urbano (IPTU) progressivo no tempo, com a edificação, utilização e parcelamento compulsórios sendo que, na última hipótese, até mesmo o objeto a que se refere seu direito 
será transmudado, desdobrando-se em outros tantos quantos sejam adequados à área do imóvel.

É dizer: as posições jurídicas outorgadas ao proprietário pelo art. 1228, caput do Código Civil são virtualidades que raramente se atualizarão na realidade, pois a possibilidade de seu exercício será sempre determinada pelas circunstâncias de fato e de direito envolventes. Os próprios termos, correntes tanto na doutrina jurídica quanto fora dela, "propriedade sobre bens de consumo", "propriedade sobre bens de produção", "propriedade personalíssima", "propriedade privada”, "propriedade pública”, "propriedade industrial” etc. - todos se referindo, de alguma maneira, ao "domínio" - expressam a existência de regramentos específicos de direito e, por consequência, a insubsistência, no direito positivo, da antiga pretensão, ainda sustentada por alguns autores, de haver uma noção de cerne fixo e definitivo para a "propriedade" (Tomasetti Júnior, $1996^{3}$ ). A norma geral e abstrata atua, no mundo da vida, assim, como um mito (Murphy \& Nagel, 2005, passim).

Este é um exemplo banal. Mas, através dele, é possível observar pelo menos duas coisas. A primeira é que tem sido exigida uma imaginação (cf. Mills, 1959) cada vez mais apurada para relacionar os conteúdos concretos das posições jurídicas às categorias abstratas da dogmática do Direito Civil - ou seja: essas categorias se parecem, cada vez mais, com decalques deformados, e afirmá-las tal como elas vêm enunciadas nos dispositivos legais faz com que o discurso pareça ser crescentemente ingênuo ou ideológico, por contraste com a vida vivida. Em reação a isso, os manuais de Direito Civil e os cursos de Direito, em geral, se veem obrigados a tratar, cada vez mais, de outras searas, como a do Direito Urbanístico, a do Direito Administrativo, a do Direito Ambiental, a do Direito

\footnotetext{
${ }^{3}$ Diz ainda o autor, em sentido idêntico ao que aqui se expressa: "Nos dias correntes, tornou-se tênue, muito tênue, o mínimo denominador comum entre as figuras de propriedade, que se diversificaram a tal ponto que, para fins práticos e teóricos, releva cada vez mais o estabelecimento de diferenciações entre os regimes de espécie, do que a descoberta dos pontos de coincidência. Uma das maiores dificuldades dogmáticas em matéria de 'propriedade' encontrase, agora, em saber se há, mesmo, um instituto jurídico da propriedade, ou se, em realidade, sob uma ilusória tematização, unificante no plano formal, não se movimentam e se entrecruzam 'institutos proprietários diversos', que multiplicaram, com suas estruturas e funções jurídicas singularizadas, a noção, o conceito e o instituto unitariamente postulados".
} 
Econômico, ou mesmo de disciplinas zetéticas ${ }^{4}$, como a Economia, para dar sustentação fática aos enunciados normativos como os do art. 1228, caput do CC; os trabalhos acadêmicos têm se declarado cada vez menos dogmáticos, e o interesse dos estudiosos tem se afastado, progressivamente, da interpretação das normas jurídicas por referência a si mesmas; e mesmo na atividade profissional, os juristas, desempenhando atividade jurisdicional ou correlata, se veem obrigados a citar cada vez mais dispositivos legais, fazendo referência a diplomas e matérias bastante diversas, em alguns momentos, para fundamentar seus pedidos ou decisões. A segunda coisa a se observar - esta, grave - é que a pessoa comum, além de perceber uma "intrusão" demasiada do Estado em suas atividades cotidianas, e ver seu modo de vida muitas vezes "indefeso" diante dessa intrusão, também deixa de se sentir representada pelas leis que thes deveriam ser as mais próximas.

A solução que se tem buscado é a de uma "politização" do Direito Civil. Por "politização", aqui, não há que se entender que o Direito Civil era, antes, "apolítico" - tratou-se nesta matéria, desde sempre, afinal de contas, dos direitos dos cidadãos perante os demais cidadãos e das fronteiras entre as esferas jurídicas destes cidadãos em face do poder do Estado -; e nem que o Direito Civil, no passado, era responsável por guardar as fronteiras entre a "esfera pública" e a "esfera privada" a partir do interior desta - pois, para além das críticas a essa visão apriorística, a disciplina sempre serviu de substrato normativo para o desenvolvimento de atividades, econômicas ou não, desempenhadas "fora de casa". Sequer se trata, obviamente, de atribuir para o Direito Civil atual um caráter "partidário". "Politizar", neste sentido, significa, primeiro, simplesmente dar um significado propriamente político para as normas jurídicas e para seus efeitos, através do apontamento de sua importância e funcionalidade para a (re)produção

\footnotetext{
${ }^{4}$ A definição de "zetética", em oposição à de "dogmática" é bem explicitada por Ferraz Júnior (2003, p. 41), para quem: "Zetética vem de zetein, que significa perquirir, dogmática vem de dokein, que significa ensinar, doutrinar. Embora entre ambas não haja uma linha divisória radical (toda investigação acentua mais um enfoque que o outro, mas sempre tem os dois), sua diferença é importante. O enfoque dogmático revela o ato de opinar e ressalva algumas das opiniões. $O$ zetético, ao contrário, desintegra, dissolve as opiniões, pondo-as em dúvida. Questões zetéticas tem uma função especulativa explícita e são infinitas. Questões dogmáticas tem uma função diretiva explícita e são finitas. Nas primeiras, o problema tematizado é configurado como um ser (que é algo?). Nas segundas, a situação nelas captada configura-se como um dever-ser (como deve-ser algo?). Por isso, o enfoque zetético visa a saber o que é uma coisa. Já o enfoque dogmático preocupa-se em possibilitar uma decisão e orientar a ação".
} 
da vida social; e, segundo, do condicionamento do exercício dos direitos ao cumprimento dessas funcionalidades. Fala-se, dessa forma, na "função social" ou "econômico-social" da propriedade, do contrato e da empresa; na vedação ao "abuso" de posições jurídicas ativas; na ilicitude de comportamentos "antissociais" no exercício de direitos etc.

Mas esta solução, novamente, tem sido encarada de uma perspectiva hierárquico-subordinativa, "de cima para baixo", ou "dos sistemas para o mundo da vida". O Direito Civil, como um Direito que atua sobre a vida cotidiana do cidadão comum, então, se vê "colonizado" por outras disciplinas. Muito se tem dito sobre a "constitucionalização" ou sobre a "publicização"6 do Direito Privado, ou ainda sobre um "Direito Civil-Constitucional" cujo inocente significado superficial - o de que o Direito Civil, como qualquer outro conjunto regulatório que se pretenda "jurídico", deve buscar seu fundamento de validade na Constituição, enquanto norma cuja posição é a mais alta na pirâmide normativa kelseniana esconde o apanágio de uma "dogmática da ausência" segundo a qual o Direito Civil, para fazer sentido na contemporaneidade, precisa ser "completado" ou “presentificado" por outras disciplinas capazes de "modernizá-lo". O corolário é o de uma revogação da autonomia normativa e epistemológica do Direito Civil.

Será este o destino do Direito Civil - a sua diluição em disciplinas mais adequadas para lidar com o mundo contemporâneo?

O trabalho que segue responde negativamente a esta questão. Ele parte, para isso, de um duplo deslocamento da noção de "politização" que foi aventada logo acima.

O primeiro deslocamento é eminentemente escalar. Se a "politização" intentada pela "constitucionalização" ou pela "publicização" do Direito Privado, ou

\footnotetext{
${ }^{5}$ Para a melhor exposição na literatura dos modelos de constitucionalização, veja-se: Afonso da Silva, 2015.

${ }^{6}$ Sobre isto e com relação à propriedade, especificamente, veja-se a posição exemplar de Borges (1999): "Com o advento da Constituição de 1988 o direito de propriedade deixa de ter sua regulamentação exclusivamente privatista, baseada no Código Civil, e passa a ser um direito privado de interesse público, sendo as regras para seu exercício determinadas pelo Direito Público e pelo Direito Privado. Este processo de publicização do direito de propriedade é fundamental para a implementação da legislação referente à proteção do meio ambiente, que impõe limites ao exercício daquele direito".
} 
ainda pelo "Direito Civil-Constitucional" (Lotufo, 2002; Moraes Tepedino, 1993; Perlingieri, 2002; Tepedino, 1999) ${ }^{7}$ pretende, hierarquicamente, fazer intervir outras searas jurídicas no Direito Civil a partir de uma perspectiva macropolítica do "Poder Administrativo" e dos "sistemas" contra o mundo da vida -, propõe-se aqui, ao invés disso, que esta "politização" atenda, quando possível, à perspectiva micropolítica através da qual diferentes modos de vida se reterritorializam na "cidade", organizando-se consoante suas próprias lógicas, para existir e coexistir, ora interagindo, ora conflitando entre si, mas a todo tempo se encontrando. Não se deve buscar, em termos político-normativos, neste sentido, a legitimação do Direito Civil apenas pela submissão e coerência de suas normas em relação à Constituição, mas também nas respostas práticas que a sua dogmática - e, talvez, só ela - pode dar, por si mesma, às demandas concretas que os citadinos - como sujeitos de direito ou como cidadãos - formulam no cotidiano, uns contra os outros, ou contra o Estado, para buscar tutela aos seus modos de vida.

Para isso, é preciso que o enfoque dogmático deixe de ser exclusivamente histórico - no sentido da norma que, conquanto positivada no passado, deve se aplicar sempre, anacronicamente, no presente, conservando a si mesma em detrimento das diferenças que desde então foram elicitadas - e se conjugue com um enfoque geográfico - no qual a cartografia das relações, nas formas que as pessoas dão a elas no seu dia-a-dia, passa a dialogar com as categorias jurídicas antecedentes, ou se torna apta a erigir novas categorias, mais próximas ao contexto tratado. Consideram-se superadas as ânsias pela revogação dos costumes em prol dos Códigos totalizantes ${ }^{8}$ : a tarefa de

\footnotetext{
${ }^{7}$ Para uma crítica e uma construção de limitações teóricas à dogmática da propriedade proposta através dos pressupostos do "Direito Civil-Constitucional", veja-se, por todos: Rodrigues Júnior, 2012.

${ }^{8}$ Nas palavras de Ehrlich (1986, p. 17-18): "Procura-se apresentar o direito que surge fora do Estado como uma concessão deste; isto aconteceu em Roma já no início do período imperial, através do ius respondendi, que era uma concessão do imperador aos juristas designados para a elaboração de leis; sua atividade é restrita às questões ainda não fixadas em lei; estabelecem-se prescrições muito rígidas para a validade do direito consuetudinário; procura-se torná-lo supérfluo ou até expressamente sem efeito através de codificações que abrangem todo o direito. Mesmo os juristas que estudam cientificamente o direito são vistos com maus olhos e, em certos casos, seu trabalho até é proibido, em decorrência da sensação, aliás justificada, de que deste trabalho também possa surgir um direito extra-estatal, o direito dos juristas. A opinião mais claramente formulada sobre esta corrente talvez tenha sido expressa por Justiniano: tam conditor quam interpres legum solus imperator iuste existimabitur, nihil hac lege derogante veteris iuris conditoribus, quia et eis hoc maiestas imperialis permisit. ["Só o imperador será considerado, com
} 
codificação e de recodificação (cf. Sacco, 1983), então, se tornará uma atividade constante ${ }^{9}$.

O segundo deslocamento é institucional. E, nesse sentido, "politizar" significa também "polemizar" - ou seja, promover a confrontação entre discursos racionais distintos, de forma implementar uma das condições mais básicas do processo democrático. Trata-se de atribuir ao Direito a dignidade de ser a linguagem, por excelência, do debate democrático, restituindo a ele o condão de ventilar, de maneira agonística, pretensões até mesmo radicalmente contrárias entre si, para que elas, nas arenas de debate competentes, possam se confrontar e convencer a plateia dos cidadãos por suas próprias razões.

\section{Dogmáticas descendentes e ascendentes}

Como forma de operacionalizar estes deslocamentos, este trabalho se vale de um par conceitual tipológico que se crê inédito, e cujo sentido deve ser aclarado desde já.

O primeiro conceito é o de "dogmática descendente". Por meio dele, são referidos os argumentos propriamente jurídicos que partem de noções, normas ou princípios abstratos e genéricos já positivados no passado para, então, buscar, dedutivamente, soluções concretas. O movimento lógico que subjaz a este tipo dogmático é propriamente descrito como sendo "de cima para baixo". Ele segue, portanto, a lógica do "Poder Administrativo", comprazendo-se na maneira mais comum de se "fazer Direito" desde a Modernidade e do advento da Era das Codificações (Wieacker, 1980, p. 365 e ss.) - cujo auge é representado, hodiernamente, pela derrocada do Direito Civil, dado o estabelecimento de

\footnotetext{
justiça, tanto o criador quanto o intérprete das leis; esta lei não diminui em nada os criadores do direito antigo, pois a autoridade imperial lhes permitiu isso"]. (...) A doutrina que cada vez se firma mais é a de que o direito consuetudinário, rubrica sob a qual de agora em diante se procura resumir todo o direito extra-estatal, com exceção do científico, é um tipo de direito subalterno, pois tanto em sua origem quanto em sua validade depende de uma concessão ou de um reconhecimento ou revalidação do legislador e este evidentemente tem a possibilidade de proibi-lo totalmente. O direito consuetudinário passa a ser desprezado, até a ser ridicularizado; as provas são dificultadas e as condições de seu reconhecimento tornadas cada vez mais complicadas".
}

${ }^{9}$ Algo neste sentido se vê, por exemplo, em: Ludwig, 2005, passim. 
pressupostos epistemológicos e normativos como os do "Direito CivilConstitucional".

O segundo conceito, que se opõe ao anterior, é o de "dogmática ascendente". Por ele se designam os argumentos, também propriamente jurídicos, que partem do cotidiano da vida vivida, ou dos usos e costumes locais desenvolvidos pelos cidadãos, para embasar e procurar tutela para os modos de vida que produzem por e para si mesmos. Através desta noção, devolve-se a agência jurígena às pessoas comuns: elas já não são mais vistas como simples destinatárias e consumidoras das normas do Direito - elas as inventam, reinventam, interpretam e reinterpretam, atribuindo-as sentidos criativos e consentâneos com seus interesses e experiências mais próximos (Certeau, 1998, p. 38 e ss.). O movimento que as "dogmáticas ascendentes" descrevem é, por isso mesmo, "de baixo para cima". Reconhecer a juridicidade deste tipo dogmático é, de certa forma, devolver ao Direito Civil a sua tarefa compilatória de codificar e recodificar, constantemente, pela via de cartografias contínuas, o objeto de sua regulação. É buscar legitimar o Direito na pratica primeiro - e só depois nos valores já positivados. As "dogmáticas ascendentes" são elicitadas, assim, como "dogmáticas da presença" contra a "dogmática da ausência" que vem negando a autonomia epistemológica e normativa do Direito Civil em decorrência da obsolescência ou incompletude dos Códigos por ele já positivados (Giorgianni, 1980; Azevedo, 2004, p. 55-63). Trata-se do mais antigo dos métodos já consagrados pela disciplina - o qual se quer provar como útil para lidar com os mais novos de seus problemas: aqueles suscitados pela Pós-Modernidade urbana.

Ora, o que se pretende não é propor a substituição de um destes tipos dogmáticos pelo outro - e muito menos o primado de um direito consuetudinário de matriz jurisprudencial em face do direito positivado em lei. Ao revés, quer-se demonstrar que, no debate sobre a "cidade" e sobre o que ela deve ser, essas dogmáticas vem sendo utilizadas de forma a reeditar as cisões, de um lado, entre o Direito Público e o Direito Privado, e, de outro, entre o Estado e a sociedade civil, conferindo renovada autonomia ao Direito Civil a despeito das intentonas colonizantes do "Poder Administrativo" sobre o mundo da vida - e que isso é feito 
pela via da confrontação das "dogmáticas descendentes" com as "dogmáticas ascendentes", as quais, então, passam a desempenhar um papel semelhante ao que as teorias democráticas liberais relegavam aos "direitos civis", ou às "liberdades negativas".

\section{O caso das restrições urbanísticas convencionais}

Para mostrar como essas coisas se dão na prática, este trabalho se vale, exemplarmente, dos debates acerca da eficácia das restrições urbanísticas convencionais de loteamentos privados.

Dentre os instrumentos jurídicos de criação e organização do espaço urbano, o do loteamento esteve à frente, historicamente, do processo de urbanização nacional: já na década de 1930 - quando, não por acaso, este processo vivia uma progressiva aceleração (perceptível não apenas pelas taxas de crescimento da população distribuídas nas zonas urbanas do país, mas também por uma alteração significativa nos costumes que se desenvolviam nessas regiões) - notava-se esta circunstância, dando-lhe testemunho os consideranda do Decreto-lei n. $58 / 37^{10}$ - o primeiro diploma legal brasileiro a prever expressamente esta forma de parcelamento do solo -, outorgado pelo então presidente Getúlio Vargas ${ }^{11}$.

\footnotetext{
${ }^{10}$ Constam dos consideranda que justificavam o Decreto-lei as seguintes palavras: "Considerando o recente desenvolvimento da loteação de terrenos para venda mediante o pagamento do preço em prestações (...) Considerando ainda que a loteação e venda de terrenos urbanos e rurais se opera frequentemente sem que aos compradores seja possível a verificação dos títulos de propriedade dos vendedores..."

${ }^{11}$ Um dos grandes defensores de uma regulação legal para os loteamentos urbanos à época, Waldemar Ferreira (1952) assim analisava o contexto histórico em que se publicou o Decreto-lei $\mathrm{n}$. 58/37: "O afluxo, que ultimamente se há verificado, quase em todo o mundo, das populações rurais para os centros urbanos, aumentando, às vezes imprevistamente, as necessidades da cohabitação, trouxe como consequência natural o descongestionamento, provocado pelas empresas que, aqui como acolá, entraram a explorar a indústria dos loteamentos de terrenos, nos arrabaldes ou subúrbios. Criou-se essa indústria diante da impossibilidade dos poderes públicos municipais enfrentarem o problema e darem-Ihe a solução adequada e até premente. No começo, tudo correu desordenadamente, de acordo com o capricho e conveniência dos loteadores profissionais, mais preocupados com seu interesse de lucro do que com o atendimento das condições de higiene ou de estética, quando não das econômicas e sociais, que confluem para a complexidade do aspecto urbanístico. Tudo isso, como é de imaginar, exigiu a interferência do poder público, a bem da coletividade, e o estabelecimento de normas gerais a que os loteamentos se subordinariam, sob a égide da lei".
} 
A posição privilegiada deste instituto jurídico na instrumentalização do crescimento das cidades do país não foi alterada desde então: a Lei Lehman (Lei n. 6.766/79), ainda vigente, pouco alterando a sua feição original, erigiu-o como o meio hábil, por excelência, para a expansão das fronteiras urbanas, definindo-o como "a subdivisão de gleba em lotes destinados a edificação, com abertura de novas vias de circulação, de logradouros públicos ou prolongamento, modificação ou ampliação das vias existentes" (art. $2^{\circ}, \S 2^{\circ}$ ).

Como consequências práticas imediatas deste protagonismo na história recente, estão o elevadíssimo número de loteamentos registrados nos Cartórios de Registros de Imóveis em todo o país (e ainda mais "loteamentos irregulares") e os vultuosos impactos econômico-sociais que distorções ou reformas do regime jurídico do instituto podem causar - ainda que respeitados o ato jurídico perfeito, a coisa julgada e o direito adquirido (art. $5^{\circ}, \mathrm{XXXVI}$ da Constituição da República). Daí o regulamento incidente sobre este instrumento ser sempre objeto de disputas pelos mais diversos grupos sociais - disputas estas partem da interpretação das normas mais gerais e abstratas incidentes sobre a espécie (tais como as constantes da Lei n. 6.76679 e de sua relação com as normas constitucionais) e vão até a interpretação e o enforcement das normas mais individuais e concretas que determinam sua aplicação (como aquelas incidentes sobre um determinado loteamento, oriundas de seu plano originário ou de lei municipal - manifestamente, das Leis de Zoneamento Urbano e dos Planos Diretores).

Estes confrontos marcam uma miríade de espaços da esfera pública (Habermas, 2014, passim) e, embora tenham para si um palco privilegiado nos campos do processo administrativo e do processo legislativo (sejam eles instaurados pelo Poder Executivo ou pelo Poder Legislativo, dos Municípios, dos Estados, do Distrito Federal ou até da União), não refogem ao Poder Judiciário, ao qual passa a caber, desde a suscitação das lides, a interpretação e a concreção (Engisch, 2004, passim) dos regulamentos urbanos, tanto geral e abstratamente, na exegese dos diplomas legislativos pertinentes, quanto individual e concretamente, na análise das normas aplicáveis a um loteamento específico, considerado em suas particularidades jurídicas e idiossincrasias 
situacionais (urbanísticas, históricas, geográficas, econômicas, sociais e ambientais).

Tornaram-se comuns, nesta seara as disputas judiciais acerca das restrições urbanísticas convencionais impostas por loteadores privados com base no art. 26, VII da Lei n. 6.766/79. Estas restrições, as quais atuam sobre o conteúdo do domínio dos imóveis que gravam, são declaradas no momento em que o plano de loteamento ingressa no mundo jurídico, e tem o condão, como se verá, de determinar o perfil sócio-espacial de um bairro nascente, estabelecendo para os titulares das situações jurídicas de direito real uma série de deveres os quais, coletivamente, impactarão o valor de seus lotes, e, pelo menos parcialmente, a forma como os moradores se relacionarão entre si por intermédio dos prédios que construírem ali.

Criadas junto do loteamento privado, estas restrições perduram junto dele, não havendo a priori estabelecimento, na lei, de prazo ou condição que as ineficacize. A lacuna normativa acaba por abrir espaço a uma série de conflitos. Os mais típicos deles se dão quando os moradores de um bairro, ou a associação que os representa, ou o loteador, ou, ainda, uma entidade coletiva cujo objeto precípuo de atuação seja a defesa da ordem urbanística, se voltam contra: (i) atos de outro(s) morador(es) que desobedecem às regras convencionais; (ii) atos da Administração Pública que olvidem a existência ou neguem a eficácia dessas regras; e (iii) leis municipais supervenientes que pretendem revogá-las.

Nesse sentido está, principalmente, em pauta, de um lado, a perpetuidade apriorística das regras do bairro, as quais são utilizadas, interpretadas, reinterpretadas e reinventadas cotidianamente pelos moradores na (re)produção de seus modos de vida locais; e, de outro lado, o comportamento oportunístico do mercado e as ditas urgências da gestão urbana - de onde provem o argumento, muito comum, de que a alteração das circunstâncias da cidade teriam feito aquelas restrições convencionais "perderem seu sentido original", motivo pelo qual a elas não se deveria dar obediência. Daí se poder interpretar esses confrontos como choques entre os fluxos de desterritorialização e a resistência territorial. Nos debates - eminentemente políticos, conquanto de pequeníssima escala - que se seguem ao conflito, são formuladas tanto "dogmáticas 
descendentes" quanto "dogmáticas ascendentes". Parte destes argumentos é ventilada pela decisão judicial, quando as lides são submetidas à apreciação do Poder Judiciário, o qual acaba por reproduzir um ou outro desses tipos dogmáticos.

A questão, então, se configura como um bom laboratório para tudo quanto se falou até aqui - e as decisões judiciais, intervenientes na política urbana local, se mostram como experimentos exemplares sobre a forma em que se apresenta, hodiernamente, a autonomia do Direito Privado.

A pesquisa apresentada por essa dissertação seguirá o seguinte roteiro:

No Capítulo 1 se fará a exposição do contexto social e urbanístico em que os loteadores atuaram, no século passado, principalmente na cidade de São Paulo, e de uma das maneiras específicas - aquela que diz com a criação de "bairros-jardim" - pelas quais eles o fizeram, estabelecendo características típicas aos bairros que construíram, as quais condiziam com modelos ideais próprios de "cidade". Além disso, far-se-á a descrição das supervenientes significações empreendidas sobre estes mesmos lugares pelos modos de vida que se territorializaram ali até o ano de 2016. Será intentada, nesse sentido, uma genealogia da noção de "cidade-jardim", desde a sua criação por Ebenezer Howard, no começo do século, até a sua transmudação final na noção de "cidadesustentável", a partir da década de 70. Estes fluxos, como se mostrará, se relacionam ao próprio "direito à cidade", tal como o descreveu Henri Lefebvre, e, portanto, dizem respeito àquilo que as pessoas "querem ser", para além do que elas "são" - implicando-se aí questões éticas, morais e políticas de toda sorte. Por fim, também serão feitas considerações gerais sobre o que se passa quando estas relações são axiomatizadas pelo "Poder Econômico", que transforma a "cidade" em um objeto de mercado, a fim de delimitar uma interpretação geral para os conflitos envolvendo as restrições urbanísticas convencionais.

O Capítulo 2 abordará a questão do ponto de vista estrito do direito positivo. Para tanto, analisar-se-ão o instituto do loteamento privado, as etapas e o sentido do processo de loteamento e, mais minudentemente, as restrições urbanísticas convencionais em si: sua função concreta e abstrata, sua natureza 
jurídica e o mecanismo jurídico através do qual elas se perpetuam, vinculando aos novos proprietários dos lotes que gravam.

Com base na construção do objeto de pesquisa empreendida pelos Capítulos anteriores, o Capítulo 3 se debruçará sobre dez anos de experiência judicial do Tribunal de Justiça de São Paulo e sobre um "leading case" do Superior Tribunal de Justiça acerca da eficácia das restrições urbanísticas convencionais. Esta experiência judicial será analisada tanto quantitativa quanto qualitativamente. Em primeiro lugar, o Capítulo apresentará o perfil geral das demandas, dividindo-as em tipos de casos. Depois, são elaborados modelos decisórios, cada qual relativo a uma série de critérios decisórios que correspondem a fatores de eficácia negativa reconhecidas para as restrições urbanísticas convencionais pelos magistrados que julgaram estes casos.

O Capítulo 4, por fim, retoma a discussão feita nesta Introdução tomando por base o material teórico e empírico dos capítulos precedentes. Seu objetivo principal é o de atribuir um sentido à multiplicidade de modelos e critérios decisórios expostos no Capítulo 3, discutindo seus efeitos a partir de uma requalificação da "segurança jurídica", vinculando-os a um renovado sentido para a "função social da propriedade", nos termos de uma "dogmática descendente" e expondo o que ressai disso nos termos de uma teoria política normativa que outorgue ao Direito Civil, conquanto autônomo, um papel específico no próprio processo democrático.

Este não é um trabalho de lege ferenda. Ele frustrará àquele que o ler à procura de uma solução simples e única para a eficácia das restrições urbanísticas convencionais - como uma lista dos fatores negativos de eficácia para estes pactos. O que se discute é o que a autonomia do Direito Civil é e o que ela pode ser, se tomar para si a tarefa de salvaguardar os modos de vida diversos que emergem dos contextos urbanos.

Não se trata de um manual de instruções, mas de mostrar, junto a fatos cotidianos, como um Direito Civil autônomo pode contribuir para a democracia. 


\section{CONCLUSÃO}

A partir de recortes zetéticos e dogmáticos que descreviam contextos sociais, econômicos, urbanísticos, históricos (Capítulo 1) e jurídico-normativos (Capítulo 2), respectivamente, esta pesquisa tomou a jurisprudência do Tribunal de Justiça de São Paulo, no período compreendido entre os anos de 2006 e 2016, e um leading case do Superior Tribunal de Justiça como laboratórios a partir dos quais pretendia verificar o nível de autonomia do Direito Privado, em geral, e do Direito Civil, em especial, sobre a matéria, no ordenamento jurídico nacional.

Procuravam-se então, sistematicamente, os diferentes fatores de eficácia negativa destas restrições convencionais, tais como os reconheciam os magistrados dessa Corte, em decorrência de a Lei n. 6.766/79 - a qual prevê a possibilidade de celebração destes pactos - não os determinar de antemão, atribuindo às disposições do loteador algo como uma eficácia ad eternum, a priori.

Revelou-se, no entanto, a partir da experiência judicial do TJ-SP, que não havia um consenso integral sobre o tema. As decisões, conquanto às vezes se citassem reciprocamente e utilizassem os mesmos marcos doutrinários, divergiam em muitos aspectos.

Diante disso, procedeu-se, primeiro, a uma categorização dos casos concretos pelo critério do tipo de conflito eficacial sobre o qual eles, predominantemente, se debruçavam. Quatro tipos de caso foram encontrados e descritos no Capítulo 3, nesse sentido, a saber: (i) aqueles em que as restrições convencionais se defrontavam com atos materiais que as desrespeitavam e que, por isso, eram qualificados como ilícitos; (ii) aqueles em que estes pactos eram desafiados por atos do Poder Executivo (consistentes em autorizações, alvarás ou licenças v.g.) que olvidavam de sua vinculatividade normativa; (iii) aqueles em que leis urbanísticas supervenientes, expressa ou implicitamente, tendiam à ineficacização destas convenções; e (iv) aqueles nos quais se pleiteava a declaração judicial da ineficácia das restrições do loteamento em virtude da sua disfuncionalidade, decorrente de alterações significativas do contexto urbano do bairro. 
A cada um desses "tipos de caso" foi dado tratamento estatístico. Desmembrando a jurisprudência do TJ-SP dessa forma, averiguou-se um consenso pacífico sobre prevalência das restrições convencionais no primeiro tipo de caso e um consenso bastante majoritário sobre a prevalência delas no segundo tipo. A divergência, no entanto, distribuída igualmente entre as Seções de Direito Público e de Direito Privado do Tribunal, se mantinha sobre os dois últimos tipos.

Foi preciso, então, analisar qualitativamente esta experiência judicial, do que decorreu uma nova indução de categorias a partir dos casos concretos. Foram elaborados, então, três modelos de decisão, sendo eles: (i) a "Solução Hely Lopes Meirelles" - que leva o nome do autor cuja obra doutrinária teria inspirado, conforme o reconheciam os julgados; (ii) a "Solução Antônio Junqueira de Azevedo" - inspirada em um parecer deste jurista; e (iii) a "Solução Herman Benjamin" - assim nomeada em virtude de o voto deste Ministro do Superior Tribunal de Justiça, por ocasião do REsp. n. 302.906/SP, ter sistematizado argumentos já inscritos na experiência pretérita do TJ-SP.

Conforme se discutiu à minúcia no Capítulo 3 , havia consensos e dissensos entre estes modelos no que dizia respeito aos resultados práticos que eles propunham para os conflitos eficaciais por que passam as restrições urbanísticas convencionais nos diferentes "tipos de caso" já descritos. Colocados em série histórica do modelo mais antigo (o da "Solução Hely Lopes Meirelles") para o mais recente (o da "Solução Herman Benjamin"), eles revelavam, contudo, uma flexibilização progressiva dos critérios decisórios do primeiro - o qual se pautava, a partir de considerações dogmáticas sobre o pacto federativo e do pacto da divisão de poderes, por critérios de competência que o autorizavam a determinar que as restrições convencionais sempre podiam ser ineficacizadas pela lei urbanística superveniente, mas nunca por outros fatores. $\mathrm{Na}$ "Solução Antônio Junqueira de Azevedo", assim, somava-se mais um fator de ineficácia para estas convenções, consistente na alteração das circunstâncias urbanísticas que os disfuncionalizassem. Por sua vez, na "Solução Herman Benjamin", a despeito de ela admitir, também, os fatores de eficácia negativa dos outros dois modelos, postulava-se que a ineficacização das "restrições urbanístico- 
convencionais" - como foram chamadas no REsp. n. 302.906/SP - deveria se dar apenas excecionalmente, sendo possível até que elas persistissem diante da lei urbanística ineficacizante, desde que não fossem disfuncionais e representassem uma maior proteção ao meio-ambiente urbano, invocando-se a função social da propriedade, o princípio do não-retrocesso em matéria ambiental e o ato jurídico perfeito como fundamentos daquela persistência.

Comparando-se os traços dos modelos decisórios às frequências de prevalência ou não-prevalência das restrições urbanísticas convencionais no período de 2006 a 2016 (Capítulo 4), constatou-se que entre eles havia um equilíbrio dinâmico: as decisões pontuais dos casos pareciam debater entre si, formulando, a cada vez, novos argumentos a favor de um ou outro modelo, a fim de, em tese, torná-lo hegemônico.

Foi possível notar, além disso, através dessa categorização, que os três modelos decisórios supunham respostas distintas a quais seriam os significados de "Direito", de "cidade" e da "relação entre o Direito e a cidade", e que eles também valoravam diferentemente as próprias restrições urbanísticas convencionais do ponto de vista jurídico e político-moral.

Para entender, especificamente, esta valoração diferencial, foi necessário tornar ainda mais concreta a investigação. Daí a necessidade de aprofundar a contextualização zetética da pesquisa.

Os novos dados, para facilitação da leitura, foram inseridos junto ao Capítulo 1. Toma-se ali, como parâmetro, o caso emblemático das "cidadesjardim" paulistanas, conforme elas foram construídas e simbolizadas nas primeiras décadas do século $X X$ e ressignificadas até 2016, em progressão genealógica. Este estudo foi especialmente pertinente, uma vez que pelo menos dois dos modelos documentos centrais para a elaboração dos modelos decisórios do Capítulo 3 (o parecer da "Solução Antônio Junqueira de Azevedo" e o REsp. n. 302.906/SP da "Solução Herman Benjamin) haviam sido dirigidos, exatamente, para disputas entabuladas nestes bairros.

Mostrou-se como a formulação inicial da noção de "cidade-jardim" por Ebenezer Howard havia se transformado no tempo, primeiro se tornando "distrito- 
jardim”, depois, já em São Paulo, "bairro-jardim” e, por fim, “cidade-sustentável”, em consonância com o arbitrário cultural dominante, com os contextos sociais em que os projetos urbanísticos se inseriam e com as linhas de força e simbolização que sobre ela atuaram em cada época.

Cruzando-se essas simbolizações com os modelos decisórios (dados discutidos no Capítulo 4), foi possível, a um só tempo: (i) determinar as funções concretas a que se orientavam os diferentes tipos de restrições urbanísticas convencionais utilizados, pelo loteador, para determinar o perfil sócio-econômico dos loteamentos que construía, e, a partir disso, a função desempenhada pelo instituto e a natureza jurídica de que ele é dotado (Capítulo 2); (ii) relacionar as simbolizações praticadas historicamente à valoração dada pelos magistrados às restrições urbanísticas convencionais; e (iii) perceber que o Direito Civil era capaz de capturar e sobrecodificar as simbolizações empreendidas pelos diferentes modos de vida territorializados nesses bairros, erigindo argumentos jurídicos, a partir deles, que se mostravam, às vezes, aptos para contrastar e até derrotar os fluxos de desterritorialização intentados pelo "Poder Administrativo" e pelo "Poder Econômico".

Os dois últimos resultados tornaram forçoso reconhecer que o Direito Civil atuava, ao menos com relação ao objeto desta pesquisa, de forma autônoma, e que a dogmática elaborada a partir dele poderia dar conta da multiplicidade de modos de vida presentes na pós-modernidade urbana, desde que se pautasse em dados do mundo da vida, reconhecendo a sua jurisgenia.

Essa era uma resposta muito diferente daquela dada pela literatura especializada, geralmente, que endereçava a questão da obsolescência das codificações totalizantes em termos de "constitucionalização" e de "publicização" do Direito Civil. Nestas correntes teóricas, o que se ventilava era a insuficiência normativa da disciplina, inclusive por caracteres que lhe seriam necessários (vide a Introdução). O que a pesquisa mostrava, todavia, é que, retomando os métodos clássicos da antiga civilística - em especial o mapeamento das relações praticadas no dia-a-dia e a compilação das normas sociais regentes destas relações - era possível redarguir de alguma forma, aos problemas postos ao Direito Civil pela pós-modernidade e, em especial, pela "cidade". 
Para discutir esta questão foram elaborados dois pares de conceitos, dos quais se tratou genericamente na Introdução e, especificamente, no Capítulo 4. O primeiro binômio, referente às "dogmáticas da ausência" e às "dogmáticas da presença", pretendia dar conta, respectivamente, dos postulados de insuficiência e obsolescência do Direito Civil, de um lado, e, de outro lado, da potencialidade que a disciplina apresentava, nos casos analisados, para se corrigir e se adaptar por si mesma. O segundo binômio, estabelecido entre as "dogmáticas descendentes" e as "dogmáticas ascendentes" se relacionava com o primeiro, mas descrevia, respectivamente, o modelo subsuntivo, necessário ao Direito Público e à instrumentalização por ele feita dos fluxos do "Poder Administrativo", primeiro, e, depois, o modelo sobresuntivo, ao qual o Direito Privado pode dar lugar para conceder jurisgenia às práticas cotidianas reiteradas e suas simbolizações, conforme constantes dos diferentes modos de vida que convivem na cidade.

Aplicando-se este instrumental conceitual aos materiais empíricos analisados, percebeu-se, ainda no Capítulo 3, que os modelos decisórios do TJSP sobre a eficácia das restrições urbanísticas convencionais se distribuíam desigualmente entre estas quatro categorias. Havia, do modelo mais antigo para o mais novo, uma abertura cada vez maior dos critérios decisórios às "dogmáticas ascendentes" - o que respondia, por sua vez, a uma multiplicação daqueles mesmos critérios: prestava-se cada vez mais atenção aos dados do mundo da vida, capturando-os através, principalmente, de cláusulas gerais e princípios ensaiando-se formas de isso acontecer, no Capítulo 4, acerca da "função social da propriedade", especialmente urbana. O caráter contramajoritário do Poder Judiciário era afirmado.

Mas não era só isso. Retornando-se ao caso dos "bairros-jardim" paulistanos e, especialmente, do Jardim América (Capítulo 4), foi possível ver, na evolução histórica da legislação urbanística de São Paulo, que debates semelhantes àqueles do Judiciário sobre as restrições urbanísticas convencionais eram travados em muitas outras arenas da esfera pública formal (i.e., institucionalizada). A posição da legislação urbanística paulistana sobre estas convenções variava no tempo, indo e vindo a reconhecer e a desconhecer a sua 
eficácia: alteravam-se as linhas de força, e, por conseguinte, as normas jurídicas. Os elementos organizados da sociedade civil - e, eminentemente, as associações/sociedades de bairros/adquirentes - pressionavam politicamente diversas instâncias do poder constituído. Quando a legislação urbanística não atendia plenamente aos seus interesses, eles refugiam, inclusive, do Poder Legislativo municipal ao Poder Executivo estadual, intentando o tombamento de seus bairros e a transformação das restrições convencionais em restrições administrativas.

O que se via eram iterações democráticas. O debate geral prosseguia, a despeito da resolução dos casos particulares (no Judiciário, por exemplo, através da estabilização do status quo pela força da coisa julgada). O papel contramajoritário da jurisdição se convertia em oportunidade para rediscussão. Os argumentos jurídicos pertinentes perpassavam uma variedade de arenas em momentos distintos. As "dogmáticas ascendentes" cada vez mais manifestavam a função, destinada na teoria política liberal aos direitos civis, de servir como limites à intrusão do Estado nos modos de vida locais e na liberdade dos citadinos atuando como mecanismos de consensualização democrática. Entre posições radicalmente diversas, acordos, compromissos e meios-termos tinham a oportunidade de se formar. De qualquer maneira, os cidadãos participavam, para muito além da representação, do processo que determinaria as regras que os vinculariam.

A questão da "segurança jurídica", a partir disso tudo, precisava ser reposta (e o foi no Capítulo 4). Dado o diagnóstico que apontara para a multiplicidade de modelos decisórios e de posições legislativas, assim como a vinculação destes ao processo de participação democrática, não havia possibilidade de se valorar essas inconstâncias como negativas apenas em homenagem a uma previsibilidade formal acerca do enforcement das normas jurídicas. Aderiu-se, então, à visão segundo a qual a "segurança jurídica", ao invés de implicar, simplesmente, aquela previsibilidade, passava a se orientar à possibilidade do controle, pela esfera pública (formal e informal, especializada e não-especializada) das motivações das decisões pelo conteúdo substancial de seus argumentos racionais e jurídicos. Esta ideia de "segurança jurídica" - a que 
se qualificou de "material", aliás, é particularmente adequada à da possibilidade de inovação por meio do Direito Civil, cujas cartografias e compilações da vida cotidiana, portanto, se veem autorizadas a formular "dogmáticas ascendentes" que propõem, a partir de uma metódica consagrada, soluções novas e passíveis de experimentação para problemas igualmente novos. 


\section{REFERÊNCIAS BIBLIOGRÁFICAS}

AFONSO DA SILVA, Virgílio. A constitucionalização do direito: os direitos fundamentais nas relações entre particulares. São Paulo: Malheiros, 2015.

O STF e o controle de constitucionalidade: deliberação, diálogo e razão pública. Revista de Direito Administrativo, n. 250, p. 197-227, 2009.

AGIER, Michel. Encontros etnográficos: interação, contexto, comparação. São Paulo: Editora UNESP, 2015.

AGUIAR JÚNIOR, Ruy Rosado de. Extinção dos contratos por incumprimento do devedor. Rio de Janeiro: AIDE Editora, 2003.

AKERBANE, Hassen. Essai d'une théorie générale de l'obligation propter rem en droit positif français. Paris: Librairie Générale de Droit et de Jurisprudence, 1957.

AKERLOF, George. The market for "lemons": quality, uncertainty and the market mechanisms. The Quarterly Journal of Economics, v. 3(4), p. 488-500, 1970.

ALBUQUERQUE FILHO, Paulo Aírton. O loteamento e desmembramento de imóvel perante o registro imobiliário. In: JACOMINO, Sérgio (org.) et al. Registro de imóveis: Estudos de direito registral imobiliário (XXIII Encontro de Oficiais de Registro de Imóveis do Brasil: Fortaleza - Ceará/1996). Porto Alegre: Sergio Antonio Fabris Editor, 1997. p. 51-64.

ALEXY, Robert. Teoria dos direitos fundamentais. São Paulo: Malheiros, 2008.

ANDRADE, Manuel A. Domingues de. Teoria geral da relação jurídica. v. I. Coimbra: Almedina, 2003.

ANTUNES, José Engrácia. A 'consuetudo mercatorum' como fonte do direito comercial. Revista de Direito Mercantil, Industrial, Econômico e Financeiro, v. 46, n. 146, p. 7-22, 2007.

APPADURAI, Arjun. Place and voice in anthropological theory. Cultural Anthropology, v. 3, n.1, p. 16-20, 1988. 
ARANTES, Rogério Bastos. Constitutionalism, the expansion of Justice and the judicialization of politics in Brazil. In: SIEDER, Rachel; SCHJOLDEN, Line; \& ANGELI, Alan. The judicialization of politics in Latin America. Nova lorque: Palgrave Macmillan, 2006.

ARRUÑADA, Benito. Organização do registro da propriedade em países em desenvolvimento. Revista de Direito Imobiliário, v. 56, p. 139 e ss., São Paulo, 2004.

ASCENSÃO, José de Oliveira. Direito civil: teoria geral. v. III. Coimbra: Editora Coimbra, 2002.

AUGÉ, Marc. Não lugares: introdução a uma antropologia da sobremodernidade. Lisboa: Editora 90 Graus, 2005.

AZEVEDO, Antônio Junqueira de. A boa fé na formação dos contratos. Revista de Direito do Consumidor, v. 3, p. 78 e ss., São Paulo, 1992.

. Estudos e pareceres de direito privado. São Paulo: Saraiva, 2004.

- Negócio jurídico e declaração negocial: noções gerais e formação da declaração negocial. São Paulo, Faculdade de Direito, Universidade de São Paulo, 1986.

- Negócio jurídico: existência, validade e eficácia. $4^{a}$ ed. São Paulo: Saraiva, 2010.

. Novos estudos e pareceres de direito privado. São Paulo: Saraiva, 2009.

- O Direito Civil tende a desaparecer? Revista de Direito Civil Contemporâneo, v.1, n.1, p. 355-364, 2014.

AZEVEDO, Aroldo de. A cidade de São Paulo: estudos de geografia urbana. v.III. [s.I.]: Editora Nacional, 1958.

AZEVEDO JÚNIOR, José Osório de. Compromisso de compra e venda. $6^{\mathrm{a}}$ ed. São Paulo: Malheiros, 2013. 
BATESON, Gregory. Naven: um esboço dos problemas sugeridos por um retrato compósito, realizado a partir de três perspectivas, da cultura de uma tribo da Nova Guiné. $2^{\mathrm{a}}$ ed. São Paulo: Edusp, 2006.

BARASSI, Lodovico. Proprietà e comproprietà. Milão: Editora Giuffrè, 1951.

BARBIERI, Jean-François. Perpétuité et perpétuation dans la théoria des droits reels: contribution à l'étude de la notion de perpetuité dans les relations juridiques. Toulouse: Service de Reproduction des Theses de L'Université des Sciences Sociales de Grenoble, 1977.

BAUMAN, Zygmunt. Confiança e medo na cidade. Rio da Janeiro: Zahar, 2005.

Vida para consumo: a transformação das pessoas em mercadoria. Rio de Janeiro: Zahar, 2008.

BENHABIB, Seyla. The rights of others. Cambridge: Cambridge University Press, 2004.

BENJAMIN, Antônio Herman. Constitucionalização do ambiente e ecologização da constituição brasileira. In: CANOTILHO, José Joaquim Gomes; LEIRE, José Rubens Morato (orgs.). Direito constitucional ambiental brasileiro. São Paulo: Saraiva, 2015.

. Princípio da proibição de retrocesso ambiental. In: Princípio da proibição de retrocesso ambiental. Brasília: Senado Federal; Comissão de Meio Ambiente, Defesa do Consumidor e Fiscalização e Controle, 2012.

BENSON, Bruce. The spontaneous evolution of commercial law. Southern Economic Journal, v. 55, p. 644-661, 1989.

BENTHAM, Jeremy [et al.]. O Panóptico. $2^{\mathrm{a}}$ ed. Belo Horizonte: Autêntica, 2008.

BESSONE, Darcy. Do contrato: teoria geral. $4^{a}$ ed. São Paulo, Saraiva, 1997.

BETTI, Emilio. Teoria geral do negócio jurídico. São Paulo: Servanda, 2008.

BEVILÁCQUA, Clóvis. Direito das coisas. v.1. São Paulo/Rio de Janeiro: Freitas Bastos, 1941. 
BEVILAQUA, Ciméa; \& LEIRNER, Piero de Camargo. Notas sobre a análise antropológica de setores do Estado brasileiro. Revista de Antropologia, v. 43, n. 2 , p. $105-140,2000$.

BIANCA, Caio Massimo. Diritto civile. 2a ed. t. III. Milão: Giufrre, 2000. . Diritto civile. t. VI. Milão: Giuffre, 1995.

BOBBIO, Norberto. Da estrutura à função: novos estudos de teoria do direito. Barueri: Editora Manole, 2007.

. Teoria geral do ordenamento jurídico. $6^{a}$ ed. Brasília: Editora Universidade de Brasília, 1995.

BOEHRER, John. How to teach a case. 1995. Disponível em: $<w w w . c a s e . h k s$.harvard.edu/casetitle.asp?caseNo=1285.0>. Acesso em: 02.10.2015.

BOLLOTI, Isabela Maria Lopes; PENTEADO, Luciano de Camargo. Venire contra factum proprium: uma análise comparativa da utilização da figura pela jurisprudência brasileira e italiana. Revista de Direito Privado, v. 61, p. 145172, São Paulo, 2015.

BONFANTE, Pietro. Criterio fondamentale dei rapporti di vicinanza. Scritti giuridici varii (Proprietà e Sevitù). Torino: UTET, 1918.

BORGES, Roxana Cardoso Brasileiro. Função ambiental da propriedade. Revista de Direito Ambiental, v. 3, p. 67-85, 1998.

BOULOS, Daniel. Abuso do direito no novo código civil. São Paulo: Editora Método, 2006.

BOURDIEU, Pierre. A distinção: crítica social do julgamento. São Paulo: Edusp; Porto Alegre: Zouk, 2007-a.

. A dominação masculina. 11ª ed. Rio de Janeiro: Bertrand Brasil, 2012. . A economia das trocas simbólicas. São Paulo: Perspectiva, 2007-b. 
. Champ du pouvoir et division du travail de domination. Texte manucrist inédit ayant servi de support de cours au Collège de France, 1985-1986. Actes de la recherche en sciences sociales, n. 190, p. 126-139, 2011.

. Efeitos de lugar. In: BOURDIEU, Pierre (coord.). A miséria do mundo. $7^{\text {a }}$ ed. Petrópolis: Vozes, 2008.

- Habitus, code et codification. Actes de la recherche em sciences sociales, v. 64, p. 40-44, 1986.

O poder simbólico. Rio de Janeiro: Difel, 1989.

BOURDIEU, Pierre; CHAMBOREDON, Jean-Claude; \& PASSERON, Jean Claude. A profissão de sociólogo: preliminares epistemológicas. Petrópolis: Vozes, 1999.

BOURDIEU, Pierre; \& EAGLETON, Terry. A doxa e a vida cotidiana: uma entrevista. In: ZIZEK, Slavoj (org.). Um mapa da ideologia. Rio de Janeiro: Contraponto, 1996. (E-book: paginação irregular).

BRAITHWAITE, John. Rules and principles: a theory of legal certainty. Australian Journal of Legal Philosophy, v. 27, p. 47-82, 2002.

CALDEIRA, Teresa Pires do Rio. Cidade de muros: crime, segregação e cidadania em São Paulo. São Paulo: Ed. 34, Edusp, 2000.

CANARIS, Klaus-Wilhelm. Pensamento sistemático e conceito de sistema na ciência do direito. $5^{\mathrm{a}}$ ed. Lisboa: Fundação Calouste Gulbekian, 2012.

CANOTILHO, José Joaquim Gomes. Direito constitucional e teoria da constituição. $2^{\mathrm{a}}$ ed. Coimbra: Almedina, 1998.

CARLOS, Ana Fani Alessandri. A cidade. 9a ed. São Paulo: Contexto, 2015.

CARLOS, Ana Fani Alessandri; VOLOCHKO, Danilo; ALVAREZ, Isabel Pinto. Introdução. In: CARLOS, Ana Fani Alessandri; VOLOCHKO, Danilo; ALVAREZ, Isabel Pinto (orgs.). A cidade como negócio. São Paulo: Contexto, p. 7-13, 2015.

CARVALHO, Afrânio de. Registro de imóveis. Rio de Janeiro: Forense, 1976. 
CARVALHO FILHO, José dos Santos. Comentários ao Estatuto da Cidade. $5^{\mathrm{a}}$ ed. São Paulo: Atlas, 2013.

CASTELLS, Manuel. La cuestión urbana. 15ª ed. [s.I.]: Siglo XXI Editores, 2014. O poder da identidade. v.2. São Paulo: Paz e Terra, 1999.

CASTRO, Torquato. Teoria da situação jurídica em direito privado nacional: estrutura, causa e título legitimário do sujeito. São Paulo: Saraiva, 1985.

CERTEAU, Michel de. A invenção do cotidiano: artes de fazer. $3^{a}$ ed. Petrópolis: Editora Vozes, 1998.

COASE, Ronald. The problem of social cost. The Journal of Law \& Economics, v. 3, p. 1-44, 1960.

CORBIN, Alain. Bastidores. In: PERROT, Michelle (org.). História da vida privada: da Revolução Francesa à Primeira Guerra. v.4. São Paulo: Companhia das Letras, 1992. p. 413-465.

CORREIA, Telma de Barros. A cidade-jardim: os conjuntos residenciais de fábricas (Brasil, 1918-1953). Anais do Museu Paulista, v. 22, n. 1, p. 161198, 2014.

COUTO E SILVA, Clóvis Veríssimo do. A obrigação como processo. Rio de Janeiro: Editora FGV, 2007.

. O princípio da boa-fé no Direito brasileiro e português. In: FRADERA, Vera Maria Jacob de (org.). O direito privado brasileiro na visão de Clóvis do Couto e Silva. Porto Alegre: Livraria do advogado, 1997.

CUNHA DE SÁ, Fernando Augusto. Abuso do direito. Coimbra: Almedina, 2005.

DANTAS, San Tiago. O conflito de vizinhança e sua composição. Rio de Janeiro: Forense, 1972.

DELEUZE, Gilles. A imanência: uma vida. In: DELEUZE, Gilles. Imagens de um filósofo da imanência. Londrina: UEL, 1997. p. 15-19. . Lógica do sentido. São Paulo: Perspectiva, 2000. 
DELEUZE, Gilles; \& GUATARRI, Felix. Mil platôs: capistalismo e esquizofrenia. v.1. $2^{\text {a }}$ ed. São Paulo: Editora 34, 2011. . Mil platôs: capitalismo e esquizofrenia. v. 3. São Paulo: Editora 34, 1996. . Mil platôs: capitalismo e esquizofrenia. v. 4. São Paulo: Editora 34, 1997. Mil platôs: capitalismo e esquizofrenia. v. 5. São Paulo: Editora 34, 1997. . O anti-Édipo: capitalismo e esquizofrenia. Lisboa: Assírio \& Alvim, 2004.

DELEUZE, Gilles; \& PARNET, Claire. Diálogos. São Paulo: Escuta, 1998.

DEMSETZ, Harold. Toward a theory of property rights. The American Economic Review, v. 57, n. 2, p. 347-359, 1967.

DERBLI, Felipe. O princípio da proibição de retrocesso ambiental na Constituição de 1988. Rio de Janeiro: Renovar, 2007.

DERRIDA, Jacques. Signature, event, context. In: Derrida reader: between the blinds. Nova lorque: Columbia University Press, 2011. p. 80-111.

DIP, Ricardo. Registro de imóveis: vários estudos. Porto Alegre: Sérgio Antônio Fabris, 2005.

DUCLOS, José. L'opposabilité: essai d'une theorie generale. Paris: Librairie Generale de Droit et de Jurisprudence, 1948.

DURKHEIM, Émile. Da divisão do trabalho social. São Paulo: Martins Fontes, 1999.

DWORKIN, Ronald. Levando os direitos a sério. São Paulo: Martins Fontes, 2002. . O império do direito. São Paulo: Martins Fontes, 1999.

EHRLICH, Eugen. Fundamentos da sociologia do direito. Brasília: Editora Universidade de Brasília, 1986.

ELIAS, Norbert. O processo civilizador. v.II. Rio de Janeiro: Zahar, 1993.

ELSTER, Jon. Ulisses liberto: estudos sobre racionalidade, pré-compromisso e restrições. São Paulo: Editora UNESP, 2009. 
ENECCERUS, Ludwig; \& NIPPERDEY, Hans Carl. Derecho civil. v. 1. trad.: Barcelona: Casa Editorial Bosch, 1953.

ENGISCH, Karl. Introdução ao pensamento jurídico. Lisboa: Fundação Calouste Gulbekian, 2001. . La idea de concreción em el derecho y em la ciência jurídica actuales. $2^{\mathrm{a}}$ ed. Granada: Comares, 2004.

ESPÍNOLA, Eduardo. Sistema do direito civil brasileiro. Rio de Janeiro: Freitas Bastos, 1944.

EVANS-PRITCHARD, Edward Evan. Os Nuer: uma descrição do modo de subsistência e das instituições políticas de um povo nilota. $2^{a}$ ed. São Paulo: Perspectiva, 2013.

FACHIN, Luiz Edson. Direito civil: sentidos, transformações e fim. Rio de Janeiro: Renovar, 2015.

FEREJOHN, John; \& PASQUINO, Pasquale. The countermajoritatian opportunity. Journal of Constitutional Law, University of Pensilvania, v. 13:2, p. 353-395, 2010.

FERNANDES JÚNIOR. As sanções e consequências do abuso do direito na jurisprudência do Superior Tribunal de Justiça. Revista de Direito Privado, v. 87, p. 99-122, São Paulo, 2018.

.Entre o 'abuso do poder econômico' e o 'abuso do direito': o caso da incorporadora oportunista. Revista de Direito Privado, v. 100, p. 73-93, São Paulo, 2019-a.

.Funcionalização da posse e do ius possessionis: do novo sentido do 'quieta non movere!' ao manejo abusivo das ações possessórias. Revista de Direito Privado, v. 72, p. 113-133, São Paulo, 2018.

O problema do controle concentrado de constitucionalidade de leis orçamentárias na jurisprudência do Supremo Tribunal Federal. Revista dos Tribunais, v. 87, p. 99-122, São Paulo, 2019-b. 
. O significado do 'abuso do direito' na jurisprudência do Superior Tribunal de Justiça. Revista de Direito Privado, v. 99, p. 49-70, São Paulo, 2019-c.

O subprime e a teoria da causa: uma análise da crise econômico financeira de 2007. O Comercialista, v.3, São Paulo, p. 10-13, 2013.

FERNANDES JÚNIOR, João Gilberto Belvel; GOMES, Gabriel Hardt. No seu devido lugar: simbolizações e disputas simbólicas em torno do Vão Livre do MASP. Trabalho apresentado na no GT "Antropologia política das situações de crise", na XIII Reunião de Antropologia do Mercosul, ocorrida de 22 a 25 de julho de 2019, em Porto Alegre/Rio Grande do Sul. Disponível em: $<$ https://www.ram2019.sinteseeventos.com.br/arquivo/downloadpublic?q=YT oyOntzOjY6InBhcmFtcyl7czozNDoiYToxOntzOjEwOiJJRF9BUIFVSVZPIjtzO jM6ljI1NSI7fSI7czoxOiJoljtzOjMyOil3YTk4NzUyMmE5NmRmNGI5ZDFkNDA 1NjMwYTdmNzJhZSI7fQ\%3D\%3D>. Visualizado em: 01.01.2020.

FERRAZ JÚNIOR, Tércio Sampaio. Introdução ao estudo do direito: técnica, decisão, dominação. $4^{\mathrm{a}}$ ed. São Paulo: Atlas, 2003.

FERREIRA, Waldemar. O loteamento de terrenos urbanos de propriedade particular e o domínio público dos espaços livres. Revista da Faculdade de Direito da Universidade de São Paulo, v. 56, p. 129-144, São Paulo, 1952.

- O loteamento de terrenos urbanos e terras rurais. Revista da Faculdade de Direito da Universidade de São Paulo, v.56, p. 152-163, São Paulo, 1961. . O loteamento e a venda de terrenos em prestações. São Paulo: Revista dos Tribunais, 1938.

FIGUEIREDO, Lúcia Valle. Disciplina urbanística da propriedade. $2^{a}$ ed. São Paulo: Malheiros, 2005.

FITZPATRICK, Daniel. Evolution and chaos in property rights systems: the Third World tragedy of contested access. The Yale Law Journal, v. 115, p. 9961048, 2006. 
FORGIONI, Paula. A interpretação dos negócios empresariais no novo Código Civil brasileiro. Revista de Direito Mercantil, Industrial, Econômico e Financeiro, v. 42, n. 130, p. 7-38, 2003.

FOUCAULT, Michel. Em defesa da sociedade. São Paulo: Martins Fontes, 1999. . Microfísica do poder. $4^{\mathrm{a}}$ ed. Rio de Janeiro: Graal, 1984.

. Outros espaços. In: FOUCAULT, Michel. Ditos e escritos III: Estética: literatura e pintura, música e cinema. Rio de Janeiro: Forense Universitária, 2011.

. Segurança, território, população. São Paulo: Martins Fontes, 2008.

. Vigiar e punir: nascimento da prisão. 14ª ed. Petrópolis: Vozes, 1996.

FURQUIM, Claudio do Amaral. O direito de construir na perspectiva urbanísticoconstitucional. Belo Horizonte: Del Rey, 2013.

GALGANO, Francesco. História do direito comercial. Lisboa: Editores, 1990.

GARGARELLA, Roberto. Latin american constitutionalism: social rights and the 'engine room' of the Constitution. Notre Dame Journal of International \& Comparative Law, v. 4:1, p. 9-18, 2014.

GASPARINI, Diógenes. O Município e o parcelamento do solo. $2^{\mathrm{a}}$ ed. São Paulo: Saraiva, 1988.

GHESTIN, Jacques. L'analyse économique de la clause générale. In: GRUNDMANN, Stefan; \& MAZEAUD, Denis (ed.). General clauses and standards in European contract law: comparative law, EC law and contract law codification. Haia: Kluwer Law International, 2006. p. 165-187.

GIORGIANNI, Michele. La morte del códice ottocentesco. Rivista di Diritto Civile, ano XXVI, p. 52-55, 1980.

GLASER, Barney G.; Strauss, Anselm. The discovery of grounded theory: strategies for qualitative research. Londres: Aldine Transaction, 2006.

GOMES, Orlando. Contratos. $26^{a}$ ed. Rio de Janeiro: Forense, 2008-a. 
. Direitos reais. $21^{\mathrm{a}}$ ed. Rio de Janeiro: Forense, 2012.

. Obrigações. $17^{\mathrm{a}}$ ed. Rio de Janeiro: Forense, 2008-b.

GONZÁLEZ, Fernando P. Méndez. A função econômica dos sistemas registrais.

Revista de Direito Imobiliário, v. 53, p. 13 e ss., São Paulo, 2002.

GRAU, Eros Roberto. O direito posto e o direito pressuposto. $7^{\text {a }}$ ed. São Paulo: Malheiros, 2008.

GUATARRI, Felix; \& ROLNIK, Suely. Micropolítica: cartografias do desejo. Petrópolis: Vozes, 1996.

GUPTA, Akhil; \& FERGUSON, James. Mais além da cultura: espaço, identidade e política da diferença. In: ARANTES, Antonio (org.). Espaço da diferença. Campinas: Editora UNICAMP, p. 21-49, 2000.

HABERMAS, Jürgen. Direito e democracia: entre facticidade e validade. v. II. Rio de Janeiro: Tempo Brasileiro, 1997.

. Mudança estrutural da esfera pública. São Paulo: Editora UNESP, 2014.

HALL, Peter. Cidades do amanhã: uma história intelectual do planejamento e do projeto urbanos no século XX. São Paulo: Perspectiva, 1988.

HART, Herbert. $O$ conceito de direito. $3^{a}$ ed. Lisboa: Fundação Calouste Gulbekian, 2001.

HARVEY, David. Cidades rebeldes: do direito à cidade à revolução urbana.São Paulo: Martins Fontes, 2014.

- Condição pós-moderna: uma pesquisa sobre as origens da mudança cultural. 15ª ed. Rio de Janeiro: Edições Loyola, 2006.

. O direito à cidade. Lutas Sociais, n. 29, p. 73-89, 2012.

- O trabalho, o capital e o conflito de classes em torno do ambiente construído nas sociedades capitalistas avançadas. Espaços e Debates, n. 6, 1982. Disponível em:

https://antropologiadeoutraforma.files.wordpress.com/2014/03/david-harvey- 
o-trabalho-o-capital-e-harvey-david-o-conflito-de-classes-em-torno-doambiente-construc3addo-nas-sociedades-capitalistas-avanc3a7adas.pdf $>$. Visualizado em: 06.01.2020.

HIRSCHL, Ran. Toward juristocracy: the origns and consequences of new constitutionalism. Massachusetts: Harvard University Press, 2004.

HOWARD, Ebenezer. Cidades-jardins de amanhã. São Paulo: Hucitec, Edusp, 1996.

. Garden cities of to-morrow. $2^{\mathrm{a}}$ ed. Londres: Swan Sonnenschein \& Co., 1902.

HUMBERT, Georges Louis Hage. Direito urbanístico e função socioambiental da propriedade urbana. Belo Horizonte: Editora Fórum, 2009.

INGOLD, Tim. The perception of the environment: essays on livelihood, dwelling and skill. Londres/Nova lorque: Routledge, 2000.

ITURRASPE, Jorge Mosset; FALCÓN, Enrique M.; PIEDECASAS, Miguel A. La frustración del contrato y la pesificación. Buenos Aires: Ed. Rubinzal Culzoni. 2002.

KELSEN, Hans. Teoria pura do Direito. $8^{\mathrm{a}}$ ed. São Paulo: Martins Fontes, 2009.

KENNEDY, Duncan. Legal formality. Journal of Legal Studies, v.2, p. 351-399, p. 1973.

LARENZ, Karl. Base del negocio jurídico y cumplimiento de los contratos. Granada: Editora Comales, 2002. . Metodologia da ciência do direito. $6^{a}$ ed. Lisboa: Fundação Calouste Gulbekian, 2012.

LATOUR, Bruno. Reagregando o social. Salvador: Edufba, 2012.

LAUWE, Paul-Henry Chombart de. A organização social no meio urbano. In: VELHO, Otávio Gilberto. O fenômeno urbano. Rio de Janeiro: Zahar, 1967. p. 113-133. 
LE CORBUSIER. A carta de Atenas. São Paulo: Hucitec, Edusp, 1993. . Planejamento urbano. $3^{\mathrm{a}}$ ed. São Paulo: Perspectiva, 2000.

LEFEBVRE, Henri. O direito à cidade. São Paulo: Centauro, 2001. . The production of space. Oxford/Cambridge: Blackwell, 1991.

LEITÃO, Luís Manuel Teles de Menezes. Direito das obrigações. $8^{a}$ ed. Coimbra: Almedina, 2009.

LIMA SOBRINHO, Barbosa. As transformações da compra e venda. Rio de Janeiro: Borsói, s.d.

LIJPHART, Arend. Modelos de democracia: desempenho e padrões de governo em 36 países. $3^{a}$ ed. Rio de Janeiro: Civilização Brasileira, 2003.

LOTUFO, Renan. Direito civil constitucional. São Paulo: Malheiros, 2002.

LUDWIG, Marcos de Campos. Usos e costumes no processo obrigacional. São Paulo: Revista dos Tribunais, 2005.

MACCORMICK, Neil. Argumentação jurídica e teoria do direito. São Paulo: Martins Fontes, 2006.

MACKAAY, Ejan; LEBLANC, Nicolette; \& DARANKOUM, Emmanuel. L'économie de la bonne foi contractuelle. In: MOORE, Benoît. Mélanges Jean Pineau. Montreal: Éditions Thémis, 2003. p. 421-459.

MAGNANI, José Guilherme Cantor. De perto e de dentro: notas para uma etnografia urbana. Revista Brasileira de Ciências Sociais, v. 17, n. 49, p. 11$29,2002$.

MALUF, Carlos Alberto Dabus. Limitações ao direito de propriedade. $2^{a}$ ed. São Paulo: Revista dos Tribunais, 2005.

MARANHÃO, Juliano Souza de Albuquerque. Positivismo lógico-inclusivo. Madri: Marcial Pons, 2012.

MARICATO, Ermínia. Metrópole, legislação e desigualdade. Estudos Avançados, v. 17, n. 48, p. 151-166, 2003. 
MARICATO, Ermínia; \& FERREIRA, João Sette Whitaker. Operação urbana consorciada: diversificação urbanística participativa ou aprofundamento da desigualdade? In: OSÓRIO, Letícia Marques (org.). Estatuto da Cidade e reforma urbana: novas perspectivas para as cidades brasileiras. Porto Alegre: Sergio Antonio Fabris Editor, 2002.

MARINO, Francisco Paulo de Crescenzo. Interpretação do negócio jurídico. São Paulo: Saraiva, 2011.

MARTINS-COSTA, Judith. A boa-fé no direito privado: critérios para sua aplicação. São Paulo: Marcial Pons, 2015.

. O direito privado como um sistema em construção: as cláusulas gerais no projeto de Código Civil brasileiro. Revista de Informação Legislativa, v. 139, p. 5-22, Brasília, 1998.

MARSHALL, Thomas Humphrey. Cidadania, classe e status. Rio de Janeiro: Zahar, 1967.

MAZZILLI, Hugo Nigro. Observações sobre loteamentos. Revista de Direito Imobiliário, v. 9:24, São Paulo, 1982.

MELLO, Marcos Bernardes. Teoria do fato jurídico: plano da existência. $12^{\mathrm{a}}$ ed. São Paulo: Saraiva, 2003.

MENDES, Gilmar Ferreira. Ação civil pública e controle de constitucionalidade. In: MILARÉ, Édis (coord.). A ação civil pública após 20 anos: efetividade e desafios. São Paulo: Revista dos Tribunais, 2005.

MENEZES CORDEIRO, António. Da boa-fé no direito civil. v. II. Coimbra: Almedina, 1984.

. Da boa-fé no direito civil. Coimbra: Almedina, 2001.

MEIRELLES, Hely Lopes. As restrições de loteamento e as leis urbanísticas supervenientes. Revista de Direito Administrativo, n. 120, p. 479-488, Rio de Janeiro, 1975.

. Direito de construir. 9a ed. São Paulo: Malheiros, 2005. 
. Direito municipal brasileiro. 16 ${ }^{\mathrm{a}}$ ed. São Paulo: Malheiros, 2008.

. Limitações urbanísticas ao uso da propriedade. Revista de Direito Administrativo, v. 53, p. 1-28, Rio de Janeiro, 1958.

MERLEAU-PONTY, Maurice. Fenomenologia da percepção. $2^{\mathrm{a}}$ ed. São Paulo: Martins Fontes, 1999.

MERTON, Robert King. Sociologia: teoria e estrutura. São Paulo: Mestre Jou, 1970.

MESSINEO, Francesco. Manuale di diritto civile e commerciale. Milão: Giuffrè, 1959.

MILLER, Mervyn; \& MILLER, Davina. Raymond Unwin: garden cities and town planning. Londres: Leicester University Press, 1992.

MILLS, C. Wright. A imaginação sociológica. $3^{\text {a }}$ ed. Rio de Janeiro: Zahar, 1959.

MONTESQUIEU, Charles de Secondat, Baron de. O espírito das leis: as formas de governo, a federação, a divisão de poderes. São Paulo: Martins Fontes, 2005.

MORAES TEPEDINO, Maria Celina. A caminho de um direito civil constitucional. Revista de Direito Civil, Imobiliário, Agrário e Empresarial, v. 17, n. 65, p. 21 32, 1993.

MOUFFE, Chantal. Sobre o político. São Paulo: WMF Martins Fontes, 2015.

MURPHY, Liam; NAGEL, Thomas. O mito da propriedade. São Paulo: Martins Fontes, 2005.

MUKAI, Toshio; ALVES, Alaor Caffé; \& LOMAR, Paulo José Villela. Loteamentos e desmembramentos urbanos: comentários à Lei n. 6.766, de 19/12/1979. São Paulo: Sugestões Literárias, 1987.

NAVES, Marcel. Bolsões de craque tomam locais nobres de SP. Exame. São Paulo. 10.09.2013. Disponível em: < https://exame.abril.com.br/brasil/bolsoes-de-craque-tomam-locais-nobre-desp/>. Visualizado em: 01.01.2020. 
NERY, Marcelo Batista; SOUZA, Altay Alves Lino de; \& ADORNO, Sergio. Os padrões urbano-demográficos da capital paulista. Estudos Avançados, v. 33, n. 97, p. 7-36, 2019.

NEUMANN, Franz. The democratic and the authoritarian state: essays in political and legal theory. Illinois: Free Press, 1957.

NÓBREGA, Flavianne. Custos e benefícios de um sistema jurídico baseado em standards: uma análise econômica da boa-fé objetiva. Economic Analysis of Law Review, v. 3, n. 2, p, 170-188, 2012.

NORBERG-SCHULZ, Christian. O fenômeno do lugar. In: NESBITT, Kate. Uma nova agenda para a arquitetura. São Paulo: Cosac Naify, 2006, p. 443-453.

OLIVA, Jaime Tadeu; \& FONSECA, Fernanda Padovesi. O 'modelo São Paulo': uma descompactação antiurbanidade na gênese da metrópole. Revista do Instituto de Estudos Brasileiros, n. 65, p. 20-56, 2016.

PARK, Robert Ezra. A cidade: sugestões para a investigação do comportamento humano no meio urbano. In: VELHO, Otávio Gilberto. O fenômeno urbano. Rio de Janeiro: Zahar, 1967a. p. 25-66.

. On social control and collective behavior. Chicago: Chicago University Press, 1967b.

PENTEADO, Luciano de Camargo. A propriedade entre fim e função social: a operatividade de uma cláusula geral. In: RODRIGUEZ, José Rodrigo; et al. (coord.). Nas fronteiras do formalismo: a função social da dogmática jurídica hoje. São Paulo: Saraiva, 2010.

. Direito das coisas. 2a ed. São Paulo: Revista dos Tribunais, 2012.

. Efeitos contratuais perante terceiros. São Paulo: Quartier Latin, 2007. . Integração de contratos incompletos. Tese (Livre-docência em Direito) Universidade de São Paulo, Faculdade de Direito de Ribeirão Preto (FDRP), Ribeirão Preto, 2013. 
. Sistema e direito privado: panorama histórico e perspectivas para uma racionalidade construtiva. Doutrinas essenciais de responsabilidade civil, v. 1, p. 33, 2011.

PEREIRA, Lafayette Rodrigues. Direito das coisas. v. I. (ed. fac-similar). Brasília: Senado Federal: Superior Tribunal de Justiça, 2004.

PERELMAN, Chaïm. Lógica jurídica: nova retórica. São Paulo: Martins Fontes, 2000.

PERLINGIERI, Pietro. Introduzione alla problematica dela proprietà. Camerino: Jovene, 1971.

. Perfis do direito civil: Introdução o direito civil constitucional. $2^{\mathrm{a}}$ ed. Rio de Janeiro, São Paulo: Renovar, 2002.

PÉTONNET, Colette. Observação flutuante: o exemplo de um cemitério parisiense. Antopolítica, n. 25, p. 99-111, 2008.

PIZA, Paulo Toledo. Ação na cracolândia deixa morador de bairro nobre apreensivo. G1. São Paulo. 04.01.2012. Disponível em: < http://g1.globo.com/sao-paulo/noticia/2012/01/moradores-de-bairro-nobrede-sp-se-dizem-apreensivos-com-viciados.html>. Visualizado em: 01.01.2020.

PLANITZ, Hans. Principios de derecho privado germanico. Barcelona: Casa Editorial Bosch, 1957.

PONTES DE MIRANDA, Francisco. Tratado de direito privado. t. I. $3^{a}$ ed. Rio de Janeiro: Borsói, 1970.

- Tratado de direito privado t. III. $3^{\text {a }}$ ed. Rio de Janeiro: Borsói, 1970.

. Tratado de direito privado. t. XIII. 3a ed. Rio de Janeiro: Borsói, 1971.

. Tratado de direito privado. t. XVIII. $3^{\text {a }}$ ed. Rio de Janeiro: Borsói, 1971.

. Tratado de direito privado. t. XXVI. $3^{\text {a }}$ ed. Rio de Janeiro: Borsói, 1971. 
PRIEUR, Michel. O princípio da 'não regressão' no coração do direito do homem e do meio ambiente. In: Princípio da proibição de retrocesso ambiental. Brasília: Senado Federal; Comissão de Meio Ambiente, Defesa do Consumidor e Fiscalização e Controle, 2012

RADBRUCH, Gustav. Filosofia do direito. 6ª ed. Coimbra: Arménio Amado, 1997.

REGO, Renato Leão. O desenho urbano de Maringá e a idéia de cidade-jardim. Acta Scientiarum, v. 23, n. 6, p. 1569-1577, 2001.

RENNER, Karl. The institutions of private law and their social functions. Londres: Routledge \& Kegan, 1949.

RIBEIRO DOS SANTOS, Fábio. Restrições urbanísticas convencionais e conflito com a legislação municipal. Revista de Direito Imobiliário, n. 71, p. 407-414, 2011.

RIPERT, Georges. Aspectos jurídicos do capitalismo moderno. [s.l.]: Freitas Bastos, 1947.

RIZZARDO, Arnaldo. Promessa de compra e venda e parcelamento do solo urbano: Leis n. 6.766/79 e 9.785/99. 10ª ed. São Paulo: Revista dos Tribunais, 2014.

RODRIGUES JÚNIOR, Otávio Luiz. Direito civil contemporâneo: estatuto epistemológico, Constituição e direitos fundamentais. $2^{a}$ ed. Rio de Janeiro: Forense Universitária, 2019.

- Propriedade e função social: exame crítico de um caso de 'constitucionalização' do direito civil. In: PINTO, Eduardo Vera-Crus; SOUSA, Marcelo Rebelo de; QUADROS, Fausto de; OTERO, Paulo (orgs.). Estudos em homenagem ao Prof. Jorge Miranda: Direito constitucional e justiça constitucional. v.3. Coimbra: Coimbra Editora, 2012, p. 61-90.

RODRIGUEZ, José Rodrigo. Como decidem as cortes? Algumas palavras sobre o papel do Direito e da doutrina no Brasil. In: LIMA, Fernando Rister de Souza (org.). Sociologia do Direito: teoria e práxis. $2^{a}$ ed. Curitiba: Juruá, 2017. p. 257-267. 
. Como decidem as cortes?: para uma crítica do direito brasileiro. Rio de Janeiro: Editora FGV, 2013.

. Segurança jurídica e mercados. Conjuntura Econômica, v. 61, n. 7, p. 3435, 2007.

RODMAN, Margaret. Multilocality and multivocality. American Anthropologist, New Series, v. 94, n. 3, p. 640-656, 1992.

RODWIN, Lloyd. Garden cities and metropolis. The Journal of Land \& Public Utility Economics, v. 21, n. 3, p. 268-281, 1945.

ROLNIK, Raquel. Para além da lei: legislação urbanística e cidadania (São Paulo 1886 - 1936). In: FERNANDES, Edésio (org.). Direito urbanístico. Belo Horizonte: Del Rey, 1998, p. 169-202.

- Territórios em conflito - São Paulo: espaço, história e política. São Paulo: Três Estrelas, 2017.

ROPPO, Enzo. O contrato. Coimbra: Almedina, 2009.

ROUBIER, Paul. Droits subjectfs et situations juridiques. Paris: Dalloz, 1963.

SACCO, Rodolfo. Codificare: modo superato di legiferare? Rivista di Diritto Civile, ano XXXIX, p. 117-135, 1983.

SANTOS, Milton. A urbanização brasileira. 5a ed. São Paulo: Edusp, 2013.

Por uma economia política da cidade: o caso de São Paulo. $2^{a}$ ed. São Paulo: Edusp, 2012.

SARLET, Ingo Wolfgang; FENSTERSEIFER, Tiago. Notas sobre a proibição de retrocesso em matéria (sócio) ambiental. In: Princípio da proibição de retrocesso ambiental. Brasília: Senado Federal; Comissão de Meio Ambiente, Defesa do Consumidor e Fiscalização e Controle, 2012

SAUSSURE, Ferdinand. Curso de linguística geral. São Paulo: Editora Cultrix, 2006. 
SAVIGNY, Friedrich Carl von. De la vocación de nuestro siglo para la legislación y la ciencia del derecho. Buenos Aires: Atalaya, 1946.

. Sistema del derecho romano atual. t. I. Madrid: Editores F. Góngora y Compañia, 1878.

SCHÄFER, Hans-Bernd. Legal rules and standards. German working paper in law and economics, paper 2, 2002.

SCHREIBER, Anderson. A proibição do comportamento contraditório: tutela da confiança e venire contra factum propium. Rio de Janeiro: Renovar, 2005.

. Direito imobiliário na perspectiva civil-constitucional. In: AZEVEDO, Fábio de Oliveira; \& MELO, Marco Aurélio Bezerra de. (orgs.). Direito imobiliário: estudos em homenagem ao professor Ricardo Pereira Lira. São Paulo: Atlas, 2015. p. 47-66.

SEGAWA, Hugo. Prelúdio da metrópole: arquitetura e urbanismo em São Paulo na passagem do século XIX ao século XX. São Paulo: Ateliê Editorial, 2000.

SEVERIANO, Fábio. A disciplina jurídica do estudo prévio de impacto de vizinhança e sua exigibilidade em face do direito de construir. Revista de Direito da Cidade, v.5, n. 1, p. 1-49, 2013.

As restrições convencionais e as leis urbanísticas no loteamento. Revista de Direito da Cidade, v. 4, n. 1, p. 1-35, 2012.

SIEBENEICHLER ANDRADE, Fábio. Da codificação: crônica de um conceito. Porto Alegre: Livraria do Advogado, 1997.

SILVA, José Afonso da. Direito urbanístico brasileiro. 6ª ed. São Paulo: Malheiros, 2010.

SILVA FILHO, Elvino. A transmissão do domínio nos compromissos de compra e venda de terrenos loteados. In: JACOMINO, Sérgio (org.) et al. Registro de imóveis: Estudos de direito registral imobiliário (XXIII Encontro de Oficiais de Registro de Imóveis do Brasil: Fortaleza - Ceará/1996). Porto Alegre: Sergio Antonio Fabris Editor, 1997. p. 33-50. 
SIMMEL, Georg. As grandes cidades e a vida do espírito. Mana, v. 11, n. 2, p. 577-591, 2005.

Questões fundamentais da sociologia: indivíduo e sociedade. Rio de Janeiro: Zahar, 2006.

SOTTANO, Jether. O compromisso de compra e venda. In: JACOMINO, Sérgio (org.) et al. Registro de imóveis: Estudos de direito registral imobiliário (XXIII Encontro de Oficiais de Registro de Imóveis do Brasil: Fortaleza Ceará/1996). Porto Alegre: Sergio Antonio Fabris Editor, 1997. p. 65-92.

SOTTO, Hernando de. The mistery of legal failure. In: SOTTO, Hernando de. The mistery of capital: why capitalism triumphs in the West and fails everywhere else. [s.I.]: Basic Books, 2003.

STRAUSS, Anselm. Qualitative analysis for social scientists. Cambridge: Cambridge University Press, 2003.

SZTAJN, Rachel; \& ZYLBERSZTAJN, Decio. Direito e economia. Rio de Janeiro: Elsevier, 2005.

TEPEDINO, Gustavo. Premissas metodológicas para a constitucionalização do direito civil. Revista de Direito do Estado, n. 2, p. 37-53, 1999.

TEUBNER, Gunther. O direito como sistema autopoiético. Lisboa: Fundação Calouste Gulbekian, 1989.

THÉRY, René. De l'utilisation a la propriété de las choses. Le droit privé français au milieu du XX siécle. t. II. Paris: LGDJ, 1950.

TOMASETTI JÚNIOR, Alcides. Execução do contrato preliminar. Tese (Doutorado em Direito) - Universidade de São Paulo, Faculdade de Direito (FD), São Paulo, 1982.

Comentários do art. $1^{\circ}$ ao 13. In: OLIVEIRA, Juarez (org.). Comentários à lei de locação de imóveis urbanos. São Paulo: Saraiva, 1992. p. 2-164.

- Perecimento do direito de domínio e improcedência da ação reivindicatória. Favela consolidada sobre terreno urbano loteado. Função 
social da propriedade. Prevalência da Constituição Federal sobre o direito comum. Revista dos Tribunais, v. 723, p. 204, 1996.

TOKER, Umut; \& TOKER, Zeynep. Revisiting Hampstead Garden Suburb: a (cautionary) tale of spatial determinism. Focus, v. 3, p. 32-37, 2006.

UNWIN, Raymond. Town planning in practice: an introduction to the art of designing cities and suburbs. Nova lorque: Benjamin Bloom, 1971.

VALENTE DA SILVA, Gilberto. As restrições do loteamento: a Prefeitura Municipal e o Registro de Imóveis. Revista de Direito Imobiliário, n. 26, p. 7-16, 1990.

VARELA, João de Matos Antunes. Das obrigações em geral. v.1. 10ª ed. Coimbra: Almedina, 2000.

VIEHWEG, Theodor. Tópica e jurisprudência. Brasília: Departamento de Imprensa Nacional, 1979.

WACQUANT, Loïc. Ghettos and anti-ghettos: an anatomy of the new urban poverty. Thesis Eleven, v. 94, n. 113, p. 113-118, 2008.

WAGNER, Roy. A invenção da cultura. São Paulo: Cosac Naify, 2010.

WATANABE, Kazuo. Da cognição no processo civil. $3^{\text {a }}$ ed. São Paulo: Perfil, 2005.

WEBER, Max. Economia e sociedade: fundamentos da sociologia compreensiva. v. 1. São Paulo: Editora UnB, 2004.

. The nature of the city. In: SENNET, Richard (ed.). Classic essays on the culture of cities. Nova Jersey: Prentice-Hall Inc., 1969. p. 23-46.

WEINGAST, Barry R. The political foundations of democracy and the rule of law. American Political Science Review, v. 91, n. 2, p. 245-263, 1997.

WIEACKER, Franz. História do direito privado moderno. $2^{\mathrm{a}}$ ed. Lisboa: Fundação Calouste Gulbenkian, 1980.

WIRTH, Louis. On cities and social life. Chicago: The University of Chicago Press, 1964. 
O urbanismo como modo de vida. In: VELHO, Otávio Gilberto. O fenômeno urbano. Rio de Janeiro: Zahar, 1967. p. 89-112.

WOLFF, Silvia Ferreira Santos. Jardim América: o primeiro bairro-jardim de São Paulo e sua arquitetura. São Paulo: Edusp, 2015.

ZIMMERMAN, Pete. Case development and teaching: communicating the results. Disponível em: <http://case.hks.harvard.edu/casetitle.asp?No=653.0>. Visualizado em: 02.10.2015. 


\section{JURISPRUDÊNCIA CONSULTADA}

\section{Superior Tribunal de Justiça}

1. BRASIL, STJ, REsp. n. 1.046.418/RJ (2008/0075932-2), Quarta Turma, rel. Min. Raul Araújo, j. 25.06.2013.

2. BRASIL, STJ, REsp. n. 302.906/SP (2001/0014094-7), Segunda Turma, rel. Min. Herman Benjamin, j. 26.08.2010.

3. BRASIL, STJ, REsp. n. 75.659/SP (1995/0049519-8), São Paulo, Quarta Turma, rel. Aldir Passarinho Júnior, j. 2005.

\section{Tribunal de Justiça de São Paulo}

1.SÃO PAULO, TJ/SP, Agl n. 1059710 (14028/05), Seção de Direito Privado, 27a Câmara, rel. des. Berenice Marcondes Cesar, j. 14.11.06

2.SÃO PAULO, TJ-SP, Apl. n. 742014-0/9, Carapicuíba (2715/97), 27ª Câmara, Seção de Direito Privado, rel. des. Berenice Marcondes Cesar, j. 16.05.06.

3.SÃO PAULO, TJ-SP, Apl. n. 855454-9/3, Ubatuba (1282/01), 32a Câmara, Seção de Direito Privado, rel. des. Kioitsi Chicuta, j. 20.07.06.

4. SÃO PAULO, TJ-SP, Apl. n. 7.026.459-0, Araçatuba (196/05), rel. des. Ulisses do Valle Ramos, j. 10.05.06

5. SÃO PAULO, TJ-SP, Apl. n. 1018456-0/4, Ibiúna (620/04), 26ª Câmara, Seção de Direito Privado, rel. des. Norival Oliva, j. 28.08.06.

6.SÃO PAULO, TJ-SP, Agl n. 574.624-5/8, São Paulo, Terceira Câmara de Direito Público, rel. des. João André de Vicenzo, j. 18.09.07

7.SÃO PAULO, TJ-SP, Apl. n. 402.255.5/2-00, São José dos Campos, Câmara Especial do Meio Ambiente, rel. des. Regina Capistrano, j. 27.09.2007. 
8. SÃO PAULO, TJ-SP, Apl. n. 312.355.5/7-00, Sorocaba, $2^{\text {a }}$ Câmara de Direito Público, rel. des. Lineu Peinado, j. 04.12.07.

9. SÃO PAULO, TJ-SP, Apl. n. 528.940.4/4-00, Ubatuba, 6a Câmara de Direito Privado, rel. des. Vito Guglielmi, j. 29.11.2007

10. SÃO PAULO, TJ-SP, EDcl n. 1.014.992-1/1, São Paulo, Seção de Direito Privado, rel. des. Romeu Ricupero, j. 14.12.07.

11. SÃO PAULO, TJ-SP, EDcl n. 4586185/8--02 (536/01), Avaré, Terceira Câmara de Direito Público, rel. des. Oliveira Passos, j. 28.11.07

12. SÃO PAULO, TJ-SP, Apl. n. 310.428.4/3-00, São Paulo, $2^{\mathrm{a}}$ Câmara de Direito Privado, rel. des. Ariovaldo Santini Teodoro, j. 02.10.07

13. SÃO PAULO, TJ-SP, Apl. n. 814351-0/1, São Paulo, 35ª Câmara, Seção de Direito Privado, rel. des. Artur Marques, j. 26.03.07

14. SÃO PAULO, TJ-SP, Apl. n. 999471-0/4, Atibaia, 29a Câmara, Seção de Direito Privado, rel. des. Pereira Calças, j. 14.11.07.

15. SÃO PAULO, TJ-SP, Apl. n. 102654-0/1, São Sebastião, 35ª Câmara, Seção de Direito Privado, rel. des. Clovis Castelo, j. 03.09.07.

16. SÃO PAULO, TJ-SP, Apl. n. 1.014.992-0/0, São Paulo, 36ª Câmara, Seção de Direito Privado, rel. des. Romeu Ricupero, j. 13.09.07

17. SÃO PAULO, TJ-SP, EDcl. n. 125.577-4/0-01, São Paulo, $5^{\text {a }}$ Câmara de Direito Privado, rel. des. Silvério Ribeiro, j. 02.04.08

18. SÃO PAULO, TJ-SP, Agl. n. 1150266-0/4, Guarulhos, $28^{\mathrm{a}}$ Câmara, Seção de Direito Privado, rel. des. Silvia Rocha Gouvea, j. 22.01.08

19. SÃO PAULO, TJ-SP, Agl. n. 1216475-0/6, Guarulhos, $31^{\text {a }}$ Câmara, Seção de Direito Privado, rel. des. Armando Toledo, j. 21.10.08

20. SÃO PAULO, TJ-SP, Apl. n. 125.577-4/9-00, São Paulo, $5^{\text {a }}$ Câmara de Direito Privado, rel. des. Silverio Ribeiro, j. 30.01.08.

21. SÃO PAULO, TJ-SP, Apl. n. 513.409-4/7-00, São Paulo, $2^{\mathrm{a}}$ Câmara de 
Direito Privado, rel. des. José Roberto Bedran, j. 11.03.08.

22. SÃO PAULO, TJ-SP, Apl. n. 157.445-4/6, Itatiba, 9a Câmara de Direito Privado, rel. des. Antonio Vilenilson, j. 11.03.08.

23. SÃO PAULO, TJ-SP, Apl. n. 691.010-5/0-00, Bragança Paulista, Câmara Especial do Meio Ambiente, rel. des. José Geraldo de Jacobina Rabello, j. 17.04.08

24. SÃO PAULO, TJ-SP, Apl. n. 499.484-4/8-00, Guarujá, $3^{a}$ Câmara de Direito Privado, rel, des. Donega Morandini, j. 29.07.08.

25. SÃO PAULO, TJ-SP, Apl. n. 258.657-4/0-00, São Paulo, 6ª Câmara de Direito Privado, rel. des. Magno Araujo, j. 27.11.08

26. SÃO PAULO, TJ-SP, Apl. n. 636.877-5/2-00, Bragança Paulista, 6 ${ }^{\mathrm{a}}$ Câmara de Direito Público, rel. des. Oliveira Santos, j. 01.12.08.

27. SÃO PAULO, TJ-SP, Apl. n. 595.415.4/4-00, São Paulo, 4ª Câmara de Direito Privado, rel. des. Francisco Loureiro, j. 4.12.08.

28. SÃO PAULO, TJ-SP, Apl. 1022209-0/0, São Paulo, 31ª Câmara, Seção de Direito Privado, rel. des. Paulo Ayrosa, j. 24.06.08

29. SÃO PAULO, TJ-SP, Apl. n. 709.881-5/7-00, São Paulo, Câmara Especial do Meio Ambiente, rel. des. Torres de Carvalho, j. 13.03.08.

30. SÃO PAULO, TJ-SP, Apl. n. 457.415-5/0-00, Ribeirão Preto, $2^{\mathrm{a}}$ Càmara de Direito Público, rel. des. Alves Bevilacqua, j. 02.12.08.

31. SÃO PAULO, TJ-SP, Apl. n. 474.994-4/2-00, São Paulo, 6ª Câmara de Direito Privado, rel. des. Isabela Gama de Magalhães, j. 11.12.08.

32. SÃO PAULO, TJ-SP, Agl. n. 1151501-0/1, Ibiúna, 26ª Câmara, Seção de Direito Privado, rel. des. Norival Oliva, j. 04.02.09.

33. SÃO PAULO, TJ-SP, Agl. n. 1275811-0/0, Guarulhos, 31ª Câmara, Seção de Direito Privado, rel. des. Armando Toledo, j. 11.08.09.

34. SÃO PAULO, TJ-SP, Agl. n. 1248846-0/0, Ubatuba, 34ª Câmara, Seção 
de Direito Privado, rel. des. Nestor Duarte, 17.08.09

35. SÃO PAULO, TJ-SP, Apl. n. 616.463.4/3, Mairinque/São Roque, $4^{\text {a }}$ Câmara de Direito Privado, rel. des. Maia da Cunha, j. 19.02.09

36. SÃO PAULO, TJ-SP, Apl. n. 626.123-5/4-00, Jundiaí, $2^{\text {a }}$ Câmara de Direito Público, rel. des. Henrique Nelson Calandra, j. 17.03.09.

37. SÃO PAULO, TJ-SP, Apl. n. 567.203-5/0-00, São Paulo, 6a Câmara de Direito Público, rel. des. Evaristo dos Santos, j. 11.05.09.

38. SÃO PAULO, TJ-SP, Apl. n. 153.103.4/7-00, Campinas, 9a Câmara de Direito Privado "B", rel. des. José Luiz Germano, j. 15.05.09.

39. SÃO PAULO, TJ-SP, Apl. n. 488.589-4/1-00, Ubatuba, Décima Câmara de Direito Privado, rel. des. Testa Marchi, j. 09.06.09.

40. SÃO PAULO, TJ-SP, Apl. n. 888.041-5/1-00, Ribeirão Preto, $2^{\text {a }}$ Câmara de Direito Público, rel. des. Vera Angrisani, j. 04.08.09.

41. SÃO PAULO, TJ-SP, Apl. n. 472.765-4/0-00, Santos, $5^{\mathrm{a}}$ Câmara de Direito Privado, rel. des. A.C. Mathias Coltro, j. 12.08.09.

42. SÃO PAULO, TJ-SP, Apl. n. 281.622-4/4-00, Campinas, $2^{\text {a }}$ Câmara de Direito Privado, rel. des. Boris Kauffman, j. 25.08.09.

43. SÃO PAULO, TJ-SP, Apl. n. 434.829-5/1-00, São Paulo, $3^{\text {a }}$ Câmara de Direito Público, rel. des. Gama Pellegrini, j. 18.08.09.

44. SÃO PAULO, TJ-SP, Apl. n. 1153844-0/0, São Paulo, 25a Câmara, Seção de Direito Privado, rel. des. Sebastião Flávio, j. 25.08.09.

45. SÃO PAULO, TJ-SP, Apl. n. 992.09.074565-4, São Paulo, 26ª Câmara de Direito Privado, rel. des. Felipe Ferreira, j. 23.09.09.

46. SÃO PAULO, TJ-SP, Apl. n. 300.700-4/7-00, São Paulo, $1^{\text {a }}$ Câmara de Direito Privado, rel. des. Elliot Akel, j. 27.10.09

47. SÃO PAULO, TJ-SP, Apl. n. 375.425-4/5-00, Paulínia/Campinas, $6^{\text {a }}$ 
Câmara de Direito Privado, rel. des. Sebastião Carlos Garcia, j. 03.12.09.

48. SÃO PAULO, TJ-SP, Apl. n. 973.430-5/1-00, Ribeirão Preto, $6^{\text {a }}$ Câmara de Direito Público, rel. des. Lemes de Campos, j. 14.12.09.

49. SÃO PAULO, TJ-SP, EDcl. n. 1014992-4/7, São Paulo, 36ª Câmara, Seção de Direito Privado, rel. des. Romeu Ricupero, j. 15.01.09

50. SÃO PAULO, TJ-SP, EDcl. n. 474.994-4/4-01, São Paulo, 6ª Câmara de Direito Privado, rel. des. Encinas Manfre, j. 18.06 .09

51. SÃO PAULO, TJ-SP, MS. n. 1267557-0/0, Guarulhos, 16ª Câmara, Seção de Direito Privado, rel. des. Walter Zeni, j. 30.06.09

52. SÃO PAULO, TJ-SP, Apl. n. 1141867-0/0, Ubatuba, 35ª Câmara de Direito Privado, rel. des. Clovis Castelo, j. 16.03.09

53. SÃO PAULO, TJ-SP, Apl. n. 765.495-5/5-00, São Paulo, 9ª Câmara de Direito Público, rel. Antonio Rulli, j. 25.03.09.

54. SÃO PAULO, TJ-SP, Apl. n. 992.04.009739-0, São Paulo, 29a Câmara de Direito Privado, rel. des. Pereira Calças, 21.10.09

55. SÃO PAULO, TJ-SP, Agl. n. 2226195-82.2015.8.26.0000, Itápolis, $1^{\text {a }}$ Câmara de Direito Público, rel. des. Marcos Pimentel Tamassia, j. 02.02.16

56. SÃO PAULO, TJ-SP, Agl. n. 2103952-39.2015.8.26.0000, Ribeirão Preto, $7^{\text {a }}$ Câmara de Direito Público, rel. des. Magalhães Coelho, j. 29.02.16

57. SÃO PAULO, TJ-SP, Agl. n. 2119069-70.2015.8.26.0000, Americana, 12a Câmara de Direito Privado, rel. des. Osvaldo de Oliveira, j. 16.03.16

58. SÃO PAULO, TJ-SP, Agl. n. 2232886-15.2015.8.26.0000, São Paulo, $8^{a}$ Câmara de Direito Privado, rel. des. Grava Brazil, j. 05.05.16

59. SÃO PAULO, TJ-SP, Agl n. 2096203-34.2016.8.26.0000, Ribeirão Preto, $2^{\mathrm{a}}$ Câmara de Direito Privado, rel. des. Rosangela Telles, j. 19.09.16

60. SÃO PAULO, TJ-SP, Ag. Interno n. 2203204-15.2015.8.26.0000, Ribeirão Preto, $10^{\mathrm{a}}$ Câmara de Direito Público, rel. des. Teresa Ramos Marques, j. 
15.02.16.

61. SÃO PAULO, TJ-SP, AgRg. n. 0001846-24.2006.8.26.0299/50001, Jandira, $3^{\text {a }}$ Câmara de Direito Privado, rel. des. Egidio Giacoia, 06.12.16.

62. SÃO PAULO, TJ-SP, Apl. n. 0002711-85.2006.8.26.0642, Ubatuba, 9a Câmara de Direito Privado, rel. des. Piva Rodrigues, j. 08.03.16

63. SÃO PAULO, TJ-SP, Apl. n. 0014136-28.2009.8.26.0053, São Paulo, $6^{\text {a }}$ Câmara de Direito Público, rel. des. Reinaldo Miluzzi, j. 16.05.16

64. SÃO PAULO, TJ-SP, Apl. n. 9000003-85.2008.8.26.0108, Jundiaí, $1^{\text {a }}$ Câmara de Direito Privado, rel. des. Christine Santini, j. 24.05.16.

65. SÃO PAULO, TJ-SP, Apl. n. 0010370-94.2015.8.26.0266, Itanhaém, $1^{\text {a }}$ Câmara de Direito Privado, rel. des. Christine Santini, j. 05.07.16

66. SÃO PAULO, TJ-SP, Apl. n. 0007944-71.2012.8.26.0248, Indaiatuba, $7^{\text {a }}$ Câmara de Direito Privado, rel. des. Mary Grün, j. 07.07.16.

67. SÃO PAULO, TJ-SP, Apl. n. 0000241-33.2014.8.26.0244, Iguape, $2^{\text {a }}$ Câmara Reservada ao Meio Ambiente, rel. des. Paulo Ayrosa, j. 07.07.16.

68. SÃO PAULO, TJ-SP, Apl. n. 4000284-96.2013.8.26.0126, Caraguatatuba, $8^{\text {a }}$ Câmara de Direito Público, rel. des. Manoel Ribeiro, j. 20.07.16

69. SÃO PAULO, TJ-SP, Apl. n. 0915178-33.2012.8.26.0037, Araraquara, $1^{\text {a }}$ Câmara de Direito Privado, rel. des. Francisco Loureiro, j. 02.08.16

70. SÃO PAULO, TJ-SP, Apl. n. 1006774-49.2014.8.26.0451, Piracicaba, 36 Câmara de Direito Privado, rel. des. Jayme Queiroz Lopes, j. 11.08.16

71. SÃO PAULO, TJ-SP, Apl. n. 1007284-73.2015.8.26.0048, Atibaia, $4^{\text {a }}$ Câmara de Direito Público, rel. des. Luis Fernando Camargo de Barros Vidal, j. 15.08.16

72. SÃO PAULO, TJ-SP, Apl. n. 0002007-62.2012.8.26.0642, Ubatuba, 29a Câmara de Direito Privado, rel. des. Fortes Barbosa, j. 24.08.16.

73. SÃO PAULO, TJ-SP, Apl. n. 0004764-79.2011.8.26.0281, Itatiba, $8^{\text {a }}$ 
Câmara de Direito Privado, rel. des. Alexandre Coelho, j. 29.08.16.

74. SÃO PAULO, TJ-SP, Apl. n. 0000901-85.2014.8.26.0451, Piracicaba, $8^{a}$ Câmara de Direito Público, rel. des. Antonio Celso Faria, j. 21.09.16.

75. SÃO PAULO, TJ-SP, Apl. n. 0001795-51.2006.8.26.0642, Ubatuba, 34a Câmara de Direito Privado, rel. des. Nestor Duarte, j. 14.09.16

76. SÃO PAULO, TJ-SP, EDcl. n. 0010855-56.2012.8.26.0248/50000, Indaiatuba, $1^{\text {a }}$ Câmara de Direito Privado, rel. des. Alcides Leopoldo e Silva Júnior, j. 14.03.16.

77. SÃO PAULO, TJ-SP, EDcl. n. 0014136-28.2009.8.26.0053/50000, São Paulo, $6^{\text {a }}$ Câmara de Direito Público, rel. des. Reinaldo Miluzzi, j. 01.08.16.

78. SÃO PAULO, TJ-SP, Apl. n. 0937383-07.2012.8.26.0506, Ribeirão Preto, $5^{\mathrm{a}}$ Câmara de Direito Privado, rel. des. Fernanda Gomes Camacho, j. 28.09.16.

79. SÃO PAULO, TJ-SP, Apl. n. 4002733-81.2013.8.26.0011, São Paulo, 9a Câmara de Direito Privado, rel. des. Angela Lopes, j. 04.10.16

80. SÃO PAULO, TJ-SP, Apl. n. 1010265-11.2015.8.26.0037, Araraquara, $1^{\text {a }}$ Câmara de Direito Privado, rel. des. Francisco Loureiro, j. 14.10.16

81. SÃO PAULO, TJ-SP, Apl. n. 1007967-27.2015.8.26.0011, Mairinque, 9a Câmara de Direito Privado, rel. des. Mauro Conti Machado, j. 25.10.16

82. SÃO PAULO, TJ-SP, Apl. n. 1000238-34.2015.8.26.0274, Itápolis, $1^{\text {a }}$ Câmara de Direito Público, rel. Marcos Pimental Tamassia, j. 23.10.16

83. SÃO PAULO, TJ-SP, Apl. n. 1003107-03.2014.8.26.0048, Atibaia, 20 Câmara Extraordinária de Direito Privado, rel. des. James Siano, j. 16.11.16

84. SÃO PAULO, TJ-SP, Apl. n. 1003070-21.2015.8.26.0248, Indaiatuba, $1^{\text {a }}$ Câmara de Direito Privado, rel. des. Marcos Pimentel Tamassia, j. 22.11.16.

85. SÃO PAULO, TJ-SP, Apl. n. 0045982-65.2009.8.26.0602, Sorocaba, $1^{\text {a }}$ Câmara de Direito Privado, rel. des. Christine Santini, j. 16.12.16.

86. SÃO PAULO, TJ-SP, Apl. n. 0023214-93.2012.8.26.0068, Barueri, $7^{\mathrm{a}}$ 
Câmara de Direito Privado, rel. des. Miguel Brandi, j. 14.12.16.

87. SÃO PAULO, TJ-SP, CC n. 0083741-16.2015.8.26.0000, Botucatu, Turma Especial, rel. des. Sidney Romano dos Reis, j. 19.02.16.

88. SÃO PAULO, TJ-SP, Agl. n. 990.10.231089-2, Guaratinguetá, Câmara Reservada ao Meio Ambiente, rel. des. Antonio Celso Aguilar Cortez, j. 24.06.10.

89. SÃO PAULO, TJ-SP, Agl. n. 990.10.430296-0, Bariri, $11^{\text {a }}$ Câmara de Direito Privado, rel. des. Paulo Ayrosa, j. 05.10.10

90. SÃO PAULO, TJ-SP, Apl. n. 994.09.283262-5, Santa Isabel, $4^{\text {a }}$ Câmara de Direito Privado, rel. des. Francisco Loureiro, j. 11.03.10.

91. SÃO PAULO, TJ-SP, Apl. n. 994.09.291355-8, São Paulo, 26ª Câmara de Direito Privado, rel. des. Felipe Ferreira, j. 28.04.10.

92. SÃO PAULO, TJ-SP, Apl. n. 990.10.077444-1, Guarujá, 5a Câmara de Direito Privado, rel. des. James Siano, j. 05.05.10.

93. SÃO PAULO, TJ-SP, Apl. n. 994.04.076679-9, Campinas, 8ª Câmara de Direito Privado, rel. des. Salles Rossi, j. 30.06.10.

94. SÃO PAULO, TJ-SP, Apl. n. 992.08.068584-5, Sorocaba, 30ª Câmara de Direito Privado, rel. des. Orlando Pistoresi, j. 14.07.10.

95. SÃO PAULO, TJ-SP, Apl. n. 994.03.073866-9, Americana, 26ª Câmara de Direito Privado, rel. des. Norival Oliva, j. 14.09.10.

96. SÃO PAULO, TJ-SP, Apl. n. 994.07.104964-7, Sorocaba, 6 ${ }^{\mathrm{a}}$ Câmara de Direito Privado, rel. des. Sebastião Carlos Garcia, j. 30.09.10.

97. SÃO PAULO, TJ-SP, Apl. n. 990.10.155055-5, Ribeirão Preto, 4ª Câmara de Direito Privado, rel. des. Francisco Loureiro, j. 25.11.10.

98. SÃO PAULO, TJ-SP, Apl. n. 992.07.052495-4, São Paulo, 35ª Câmara de Direito Privado, rel. des. José Malerbi, j. 13.12.10

99. SÃO PAULO, TJ-SP, Apl. n. 994.00.073177-9, São Paulo, 9a Câmara de 
Direito Privado, rel. des. Viviane Nicolau, j. 16.11.10.

100. SÃO PAULO, TJ-SP, EDcl. n. 992.04.009739-0/50000, 29a Câmara de Direito Privado, rel. des. Pereira Calças, j. 10.02.10.

101. SÃO PAULO, TJ-SP, EDcl. n. 992.03.020244-1/50003, São Paulo, 27a Câmara de Direito Privado, rel. des. Campos Petroni, j. 09.11.10

102. SÃO PAULO, TJ-SP, EDcl. n. 994.03.073866-9/50000, Americana, 26 ${ }^{\mathrm{a}}$ Câmara de Direito Privado, rel. des. Norival Oliva, j. 23.11.10

103. SÃO PAULO, TJ-SP, Apl. n. 994.03.060375-3, Cotia, $3^{\text {a }}$ Câmara de Direito Privado, rel. des. Adilson de Andrade, j. 23.02.10.

104. SÃO PAULO, TJ-SP, Apl. n. 994.01.031746-0, Jaú, 9a Câmara de Direito Privado, rel. des. Viniani Nicolau, j. 24.08.10

105. SÃO PAULO, TJ-SP, Agl. n. 994.09.337584-6, Barueri, $3^{a}$ Câmara de Direito Privado, rel. des. Egidio Giacoia, j. 28.09.10

106. SÃO PAULO, TJ-SP, Apl. n. 994.08.093967-3, Sorocaba, 2a Câmara de Direito Público, rel. designado des. Henrique Nelson Calandra, 06.07.10.

107. SÃO PAULO, TJ-SP, Apl. n. 992.08.074015-3, São Bernardo do Campo, $27^{a}$ Câmara de Direito Privado, rel. des. Berenice Marcondes Cesar, j. 16.11.10.

108. SÃO PAULO, TJ-SP, Agl. n. 0234825-06.2011.8.26.0000, São José dos Campos, $13^{a}$ Câmara de Direito Público, rel. des. Borelli Thomaz, j. 23.11.11.

109. SÃO PAULO, TJ-SP, Agl. n. 0078049-75.2011.8.26.0000, Jaú, $12^{\mathrm{a}}$ Câmara de Direito Público, rel. des. Osvaldo de Oliveira, j. 31.08.11.

110. SÃO PAULO, TJ-SP, Agl. n. 0095393-69.2011.8.26.0000, Guarulhos, $2^{\mathrm{a}}$ Câmara de Direito Público, rel. des. Alves Bevilacqua, j. 22.11.11.

111. SÃO PAULO, TJ-SP, Apl. n. 9219435-42.2008.8.26.0000, Mairinque, 5a Câmara de Direito Privado, rel. des. James Siano, j. 23.02.11.

112. SÃO PAULO, TJ-SP, Apl. n. 9199603-91.2006.8.26.0000, São José dos 
Campos, 34 Câmara de Direito Privado, rel. des. Nestor Duarte, j. 10.10.11.

113. SÃO PAULO, TJ-SP, Apl. n. 0191058-20.2008.8.26.0000, São Paulo, Câmara Reservada ao Meio Ambiente, rel. des. João Negrini Filho, j. 30.06.11.

114. SÃO PAULO, TJ-SP, Apl. n. 0091210-94.2007.8.26.0000, Guarujá, 9a Câmara de Direito Privado, rel. des. Viviane Nicolau, j. 12.07.11.

115. SÃO PAULO, TJ-SP, Apl. n. 9182158-94.2005.8.26.0000, Indaiatuba, $1^{\text {a }}$ Câmara de Direito Privado, rel. des. Elliot Akel, j. 26.07.11.

116. SÃO PAULO, TJ-SP, Apl. n. 9159890-75.2007.8.26.0000, F.D. Itirapina/Rio Claro, $32^{a}$ Câmara de Direito Privado, rel. Francisco Occhiuto Júnior, j. 04.08.11.

117. SÃO PAULO, TJ-SP, Apl. n. 9189163-36.2006.8.26.0000, Campinas, $3^{\text {a }}$ Câmara de Direito Privado, rel. des. Carlos Alberto Garbi, j. 27.09.11.

118. SÃO PAULO, TJ-SP, Apl. n. 9104392-57.2008.8.26.0000, Barueri, $1^{\text {a }}$ Câmara de Direito Privado, rel. des. Paulo Eduardo Razuk, j. 27.09.11

119. SÃO PAULO, TJ-SP, Apl. n. 0146855-41.2006.8.26.0000, São Paulo, $3^{\text {a }}$ Câmara de Direito Privado, rel. des. Egidio Giacoia, j. 29.11.11.

120. SÃO PAULO, TJ-SP, Apl. n. 0165744-43.2006.8.26.0000, São Paulo, Câmara Reservada ao Meio Ambiente, rel. des. João Negrini Filho, j. 30.06.11.

121. SÃO PAULO, TJ-SP, Apl. n. 9153523-45.2001.8.26.0000, São Paulo, $4^{a}$ Câmara de Direito Privado, rel. des. Carlos Henrique Miguel Trevisan, j. 24.11.11.

122. SÃO PAULO, TJ-SP, Apl. n. 0006240-66.2003.8.26.0659, Vinhedo, $4^{a}$ Câmara de Direito Privado, rel. des. Francisco Loureiro, j. 09.06.11

123. SÃO PAULO, TJ-SP, CC n. 0170115-74.2011.8.26.0000, Ribeirão Preto, Turma Especial de Direito Público, rel. des. Torres de Carvalho, j. 16.09.11.

124. SÃO PAULO, TJ-SP, Apl. n. 9132158-22.2007.8.26.0000, Guarujá, $3^{\text {a }}$ Câmara de Direito Privado, rel. des. Jesus Lofrano, j. 08.11.11. 
125. SÃO PAULO, TJ-SP, Apl. n. 9199603-91.2006.8.26.0000, São José dos Campos, $34^{\mathrm{a}}$ Câmara de Direito Privado, rel. des. Nestor Duarte, j. 02.06.14

126. SÃO PAULO, TJ-SP, Apl. n. 9145335-19.2008.8.26.0000, Ubatuba, 319 Câmara de Direito Privado, rel. des. Antonio Rigolin, j. 15.03.11.

127. SÃO PAULO, TJ-SP, Apl. n. 9135978-49.2007.8.26.0000, São Paulo, 25a Câmara de Direito Privado, rel. des. Amorim Cantuária, j. 29.03.11

128. SÃO PAULO, TJ-SP, Apl. n. 9058893-21.2006.8.26.0000, Guarujá, $6^{\text {a }}$ Câmara de Direito Privado, rel. des. Roberto Solimene, j. 06.10.11.

129. SÃO PAULO, TJ-SP, Apl. n. 9117870-69.2007.8.26.0000, Itatiba, $12^{\mathrm{a}}$ Câmara de Direito Privado, rel. des. Cerqueira Leite, j. 09.11.11.

130. SÃO PAULO, TJ-SP, EDcl. n. 0155055-95.2010.8.26.0000/50000, Ribeirão Preto, $4^{\mathrm{a}}$ Câmara de Direito Privado, rel. des. Francisco Loureiro, j. 07.04.11.

131. SÃO PAULO, TJ-SP, Apl. n. 0003980-91.2008.8.26.0642, Ubatuba, 32a Câmara de Direito Privado, rel. des. Kioitsi Chicuta, j. 07.04.2011

132. SÃO PAULO, TJ-SP, Apl. n. 9280041-36.2008.8.26.0000, São Paulo, Câmara Reservada ao Meio Ambiente, rel. des. Eduardo Braga, j. 20.10.11

133. SÃO PAULO, TJ-SP, Apl. n. 9127236-69.2006.8.26.0000, Campinas, $28^{\mathrm{a}}$ Câmara de Direito Privado, rel. des. Júlio Vidal, j. 01.03.11.

134. SÃO PAULO, TJ-SP, Apl. n. 0101313-64.2008.8.26.0053, São Paulo, Câmara Reservada ao Meio Ambiente, rel. des. Torres de Carvalho, j. 30.06.11.

135. SÃO PAULO, TJ-SP, ADIn. n. 0225476-76.2011.8.26.0000, São Paulo, Órgão Especial, rel. des. De Santi Ribeiro, j. 01.08.2012.

136. SÃO PAULO, TJ-SP, Agl. n. 0039241-98.2011.8.26.0000, Bragança Paulista, $1^{\text {a }}$ Câmara Reservada ao Meio Ambiente, rel. des. Ruy Alberto Leme Cavalheiro, j. 18.10.2012.

137. SÃO PAULO, TJ-SP, Agl. n. 0095393-69.2011.8.26.0000, Guarulhos, $3^{\mathrm{a}}$ 
Câmara de Direito Privado, rel. des. Adilson de Andrade, 20.03.2012.

138. SÃO PAULO, TJ-SP, Agl. n. 0209727-19.2911.8.26.0000, Guarulhos, $2^{\text {a }}$ Câmara de Direito Público, rel. des. Alves Bevilacqua, j. 20.03.2012.

139. SÃO PAULO, TJ-SP, Agl. n. 0214259-36.2011.8.26.0000, São Paulo, Câmara Reservada ao Meio Ambiente, rel. des. Eduardo Braga, j. 19.07.2012.

140. SÃO PAULO, TJ-SP, Agl. n. 0123689-67.2012.8.26.0000, São Paulo, Câmara Reservada ao Meio Ambiente, rel. des. Ruy Alberto Leme Cavalheiro, j. 16.08 .2012 .

141. SÃO PAULO, TJ-SP, AgRg. 0108164-45.2012.8.26.0000/50000, São Paulo, $18^{\circ}$ Grupo de Câmaras de Direito Privado, rel. des. José Malerbi, j. 22.10.2012.

142. SÃO PAULO, TJ-SP, Apl. 0088959-06.2007.8.26.0000, Guarujá, $10^{\text {a }}$ Câmara de Direito Privado, rel. des. Elcio Trujilo, j. 27.11.2012

143. SÃO PAULO, TJ-SP, Agl. n. 0209727-19.2011.8.26.0000, Guarulhos, $3^{\text {a }}$ Câmara de Direito Privado, rel. des. Viviane Nicolau, j. 11.12.2012

144. SÃO PAULO, TJ-SP, Agl. n. 0201049-78.2012.8.26.0000, Ribeirão Preto, $5^{\text {a }}$ Câmara de Direito Privado, rel. des. Edson Luiz de Queiroz, j. 19.12.2012.

145. SÃO PAULO, TJ-SP, Apl. n. 0001138-85.2010.8.26.0152, Cotia, $10^{\text {a }}$ Câmara de Direito Privado, rel, des. Elcio Trujillo, j. 31.01.2012

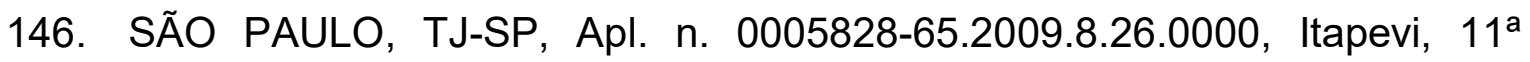
Câmara de Direito Público, rel. des. Oscild de Lima Júnior, j. 27.02.2012

147. SÃO PAULO, TJ-SP, Apl. n. 9124193-56.2008.8.26.0000, Araraquara, $5^{\text {a }}$ Câmara de Direito Privado, rel. des. Moreira Viegas, j. 29.02.2012.

148. SÃO PAULO, TJ-SP, Apl. n. 9220150-84.2008.8.26.0000, Mairiporã, $8^{\text {a }}$ Câmara de Direito Privado, rel. des. Luiz Ambra, j. 14.03.2012.

149. SÃO PAULO, TJ-SP, Apl. n. 9194234-58.2002.8.26.0000, Cubatão, Câmara Reservada ao Meio Ambiente, rel. des. Torres de Carvalho, j. 
29.03.2012.

150. SÃO PAULO, TJ-SP, Apl. n. 0005983-10.2008.8.26.0451, Piracicaba, $6^{\text {a }}$ Câmara de Direito Privado, rel. des. Fortes Barbosa, j. 19.03.2012

151. SÃO PAULO, TJ-SP, Apl. n. 9282703-70.2008.8.26.0000, Franca, $8^{\mathrm{a}}$ Câmara de Direito Privado, rel. des. Luiz Ambra, j. 18.04.2012.

152. SÃO PAULO, TJ-SP, Apl. n. 0007725-22.2008.8.26.0079, São Paulo, $3^{a}$ Câmara de Direito Privado, rel. des. Carlos Alberto Garbi, j. 08.05.12.

153. SÃO PAULO, TJ-SP, Apl. n. 0133591-89.2006.8.26.0053, São Paulo, $12^{\mathrm{a}}$ Câmara de Direito Público, rel. des. Osvaldo de Oliveira, j. 09.05.2012

154. SÃO PAULO, TJ-SP, Apl. n. 0004235-04.2010.8.26.0132, Catanduva, $1^{\text {a }}$ Câmara de Direito Público, rel. des. Castilho Barbosa, j. 26.06.2012

155. SÃO PAULO, TJ-SP, Apl. n. 0002179-55.2004.8.26.0360, Mococa, 9a Câmara de Direito Público, rel. des. Oswaldo Luiz Palu, 04.07.2012

156. SÃO PAULO, TJ-SP, Apl. n. 0042090-39.2007.8.26.0564, São Bernardo do Campo, 5a Câmara de Direito Privado, rel. des. Edson Luiz Queiroz, j. 11.07.2012

157. SÃO PAULO, TJ-SP, Apl. n. 0003699-04.2009.8.26.0642, Ubatuba, 25a Câmara de Direito Privado, rel. des. Marcondes D'Angelo, j. 18.07.2012

158. SÃO PAULO, TJ-SP, Apl. n. 9188050-76.2008.8.26.0000, Guaíra, 10a Câmara de Direito Privado, rel. des. Marcia Regina Dalla Déa Barone, j. 04.09.2012

159. SÃO PAULO, TJ-SP, Apl. n. 9121517-38.2008.8.26.0000, Guarujá, $7^{\text {a }}$ Câmara de Direito Público, rel. des. Coimbra Schmidt, j. 11.09.2012.

160. SÃO PAULO, TJ-SP, Apl. n. 0009423-69.2009.8.26.0292, Jacareí, 5 ${ }^{\mathrm{a}}$ Câmara de Direito Privado, rel. des. Edson Luiz de Queiroz, 05.09.2012

161. SÃO PAULO, TJ-SP, Apl. 9173162-39.2007.8.26.0000, Suzano, Câmara Resercada ao Meio Ambiente, rel. des. Torres de Carvalho, j. 27.09.2012 
162. SÃO PAULO, TJ-SP, Apl./Reexame Necessário n. 900012136.2005.8.26.0506, Ribeirão Preto, 9a Câmara de Direito Público, rel. des. Oswaldo Luiz Palu, j. 17.10.2012.

163. SÃO PAULO, TJ-SP, Apl. n. 0009583-94.2009.8.26.0292, Jacareí, $5^{\mathrm{a}}$ Câmara de Direito Privado, rel. des. Edson Luiz de Queiroz, j. 17.10.2012.

164. SÃO PAULO, TJ-SP, Apl. n. 0017663-72.2009.8.26.0510, Rio Claro, $1^{\text {a }}$ Câmara Reservada ao Meio Ambiente, rel. des. Paulo Alcides, j. 18.10.2012

165. SÃO PAULO, TJ-SP, Apl. n. 9058581-40.2009.8.26.0000, Guarujá, $3^{\text {a }}$ Câmara de Direito Privado, rel. des. José Pazine Neto, 30.10.2012

166. SÃO PAULO, TJ-SP, Apl. n. 0128870-94.2006.8.26.0053, São Paulo, $3^{\text {a }}$ Turma de Direito Público, rel. des. Antonio Carlos Malheiros, j. 15.05.2012.

167. SÃO PAULO, TJ-SP, Apl. n. 0004117-10.2009.8.26.0587, São Sebastião, $9^{\text {a }}$ Câmara de Direito Público, rel. des. Oswaldo Luiz Palu, j. 05.09.2012.

168. SÃO PAULO, TJ-SP, Apl. n. 0012202-27.2001.8.26.0405, Osasco, $9^{\mathrm{a}}$ Câmara de Direito Público, rel. des. Rebouças de Carvalho, j. 14.11.2012.

169. SÃO PAULO, TJ-SP, Cautelar Inominada n. 0448535-26.2010.8.26.0000, Catanduva, $1^{\text {a }}$ Câmara de Direito Público, rel. des. Castilho Barbosa, j. 12.06.2012.

170. SÃO PAULO, TJ-SP, CC. n. 0295164-28.2011.8.26.0000, São Paulo, Turma Especial de Direito Público, rel. João Negrini Filho, j. 10.02.2012.

171. SÃO PAULO, TJ-SP, CC. n. 02661129-23.2011.8.26.0000, São Paulo, Turma Especial de Direito Público, rel. João Negrini Filho, j. 10.02.2012.

172. SÃO PAULO, TJ-SP, EDcl. n. 0075292-74.2012.8.26.0000/50000, Mococa, $27^{\text {a }}$ Câmara de Direito Privado, rel. des. Campos Petroni, 04.12.2012.

173. SÃO PAULO, TJ-SP, EDcl. n. 0042090-39.2007.8.26.0564/50000, São Bernardo do Campo, $5^{\text {a }}$ Câmara de Direito Privado, rel. des. Edson Luiz de Queiroz, j. 26.09.2012. 
174. SÃO PAULO, TJ-SP, EDcl. n. 0005031-53.2011.8.26.0248/50000, Indaiatuba, $8^{\mathrm{a}}$ Câmara de Direito Privado, rel. des. Salles Rossi, 14.11.2012.

175. SÃO PAULO, TJ-SP, Agl. n. 0154228-79.2013.8.26.0000, Ribeirão Preto, 10ª Câmara de Direito Público, rel. des. Antonio Carlos Villen, j. 19.08.2013.

176. SÃO PAULO, TJ-SP, Agl. n. 0224764-86.2011.8.26.0000, São Sebastião, $1^{\text {a }}$ Câmara Reservada ao Meio Ambiente, rel. des. Torres de Carvalho, j. 05.09.2013.

177. SÃO PAULO, TJ-SP, Agl. n. 2021949-95.2013.8.26.0000, Americana, $1^{\text {a }}$ Câmara de Direito Público, rel. des. Luís Francisco Aguilar Cortez, j. 10.12.2013.

178. SÃO PAULO, TJ-SP, Apl. n. 0169105-97.2008.8.26.0000, Presidente Epitácio, $2^{\text {a }}$ Câmara Reservada ao Meio Ambiente, rel. des. Roberto Midolla, j. 28.02.2013.

179. SÃO PAULO, TJ-SP, Apl. n. 9173162-39..2007.8.26.0000, Suzano, $1^{\text {a }}$ Câmara Reservada ao Meio Ambiente, rel. des. Torres de Carvalho, j. 21.03.2013.

180. SÃO PAULO, TJ-SP, Apl. n. 0002354-13-2007.8.26.0144, Mogi-Mirim, $2^{\text {a }}$ Câmara Reservada ao Meio Ambiente, rel. des. Paulo Ayrosa, j. 21.03.2013.

181. SÃO PAULO, TJ-SP, Apl. n. 0134591-56.2008.8.26.0053, São Paulo, 10ª Câmara de Direito Público, rel. des. Urbano Ruiz, j. 08.04.2013.

182. SÃO PAULO, TJ-SP, Apl. n. 9195084-05.2008.8.26.0000, Rio Claro, $1^{\text {a }}$ Câmara de Direito Privado, rel. des. Claudio Godoy, j. 09.04.2013.

183. SÃO PAULO, TJ-SP, Apl. n. 0017288-75.2008.8.26.0132, Catanduva, $2^{2}$ Câmara de Direito Privado, rel. des. João Pazine Neto, j. 18.04.2013.

184. SÃO PAULO, TJ-SP, Apl. n. 0004657-26.2008.8.26.0318, Leme, $1^{\text {a }}$ Câmara de Direito Privado, rel. des. Rui Cascaldi, j. 16.04.2013.

185. SÃO PAULO, TJ-SP, Apl. n. 0000421-62.2007.8.26.0416, Panorama, $1^{\mathrm{a}}$ Câmara Reservada ao Meio Ambiente, rel. des. Torres de Carvalho, 
18.04.2013.

186. SÃO PAULO, TJ-SP, Apl. n. 9124060-48.2007.8.26.0000, Mogi das Cruzes, $1^{\text {a }}$ Câmara de Direito Privado, rel. des. Cláudio Godoy, j. 24.04.2013.

187. SÃO PAULO, TJ-SP, Apl. n. 0115817-94.2009.8.26.0100, São Paulo, $2^{a}$ Câmara Reservada ao Meio Ambiente, rel. des. Roberto Midolla, j. 25.04.2013.

188. SÃO PAULO, TJ-SP, Apl. n. 0029682-65.2005.8.26.0053, São Paulo, $1^{a}$ Câmara Reservada ao Meio Ambiente, des. Ruy Alberto Leme Cavalheiro, j. 18.04.2013.

189. SÃO PAULO, TJ-SP, Apl. n. 0001391-36.2005.8.26.0318, Leme, $1^{\mathrm{a}}$ Câmara Reservada ao Meio Ambiente, rel. des. Ruy Alberto Leme Cavalheiro, j. 18.04.2013.

190. SÃO PAULO, TJ-SP, Apl. n. 0024081-47.2008.8.26.0482, Presidente Prudente, $2^{a}$ Câmara Reservada ao Meio Ambiente, rel. des. Souza Nery, j. 25.04.2013.

191. SÃO PAULO, TJ-SP, Apl. n. 0223618-06.2008.8.26.0100, São Paulo, $8^{a}$ Câmara de Direito Privado, rel. des. Luiz Ambra, j. 22.05.2013.

192. SÃO PAULO, TJ-SP, Apl. n. 0007780.60.2007.8.26.0223, Guarujá, $3^{a}$ Câmara de Direito Privado, rel. des. João Pazine Neto, j. 28.05.2013.

193. SÃO PAULO, TJ-SP, Apl. n. 0003174-18.2008.26.0299, Barueri, $8^{a}$ Câmara de Direito Privado, rel. des. Luiz Ambra, j. 12.06.2013.

194. SÃO PAULO, TJ-SP, Apl. n. 0035148-87.2008.8.26.0068, Barueri, $8^{a}$ Câmara de Direito Privado, rel. Luiz Ambra, j. 12.04.2013.

195. SÃO PAULO, TJ-SP, Apl. n. 0007899-79.2008.8.26.0451, Piracicaba, $32^{a}$ Câmara de Direito Privado, rel. des. Rocha de Souza, j. 20. 06.2013.

196. SÃO PAULO, TJ-SP, Apl. n. 0016398-66.2011.8.26.0477, Praia Grande, 5a Câmara de Direito Público, rel. des. Leonel Costa, j. 10.02.2013.

197. SÃO PAULO, TJ-SP, Apl. n. 0014641-30.2008.8.26.0481, Presidente 
Epitácio, $1^{\text {a }}$ Câmara Reservada ao Meio Ambiente, rel. des. Torres de Carvalho, j. 20.06.2013.

198. SÃO PAULO, TJ-SP, Apl. n. 0000935-38.2011.8.26.0654, Cotia, $8^{a}$ Câmara de Direito Privado, rel. des. Luiz Ambra, j. 07.08.2013.

199. SÃO PAULO, TJ-SP, Apl. n. 0025739-73.2011.8.26.0071, Bauru, $8^{a}$ Câmara de Direito Privado, rel. des. João Carlos Garcia, j. 13.08.2013.

200. SÃO PAULO, TJ-SP, Apl. n. 0024974-74.2002.8.26.0053, São Paulo, $1^{\text {a }}$ Câmara Reservada ao Meio Ambiente, rel. des. Ruy Alberto Leme Cavalheiro, j. 05.09.2013.

201. SÃO PAULO, TJ-SP, Apl. n. 0027127-18.2003.8.26.0224, Guarulhos, $12^{\mathrm{a}}$ Câmara de Direito Público, rel. des. Osvaldo de Oliveira, j. 18.09.2013.

202. SÃO PAULO, TJ-SP, Apl. n. 0018122-12.2010.8.26.0099, Bragança Paulista, $2^{a}$ Câmara Reservada ao Meio Ambiente, rel. des. Souza Nery, j. 19.09.2013.

203. SÃO PAULO, TJ-SP, Apl. n. 9162359-60.2008.8.26.0000, São José dos Campos, $9^{a}$ Câmara de Direito Público, rel. des. Rebouças de Carvalho, j. 23.10.2013.

204. SÃO PAULO, TJ-SP, Apl. n. 0007249-14.2012.8.26.0153, Cravinhos, $5^{\text {a }}$ Câmara de Direito Privado, rel. des. Edson Luiz de Queiroz, j. 30.10.2013.

205. SÃO PAULO, TJ-SP, Apl. n. 0136055-80.2008.26.0000, Guarujá, $1^{\text {a }}$ Câmara Extraordinária de Direito Privado, rel. des. Beretta de Silveira, j. 14.11.2013.

206. SÃO PAULO, TJ-SP, Apl. . 0002530-15.2010.8.26.0361, Mogi das Cruzes, $2^{\mathrm{a}}$ Câmara Reservada ao Meio Ambiente, rel. des. Paulo Alcides, j. 13.12.2013.

207. SÃO PAULO, TJ-SP, Apl. n. 0001717-12.2000.8.26.0337, Mairinque, $9^{\mathrm{a}}$ Câmara de Direito Público, rel. des. Rebouças de Carvalho, j. 18.12.2013.

208. SÃO PAULO, TJ-SP, CC. n. 0074126-70.2013.8.26.0000, Mogi-Mirim, Turma Especial de Direito Público, rel. des. Sidney Romano dos Reis, rel. 
21.06.2013.

209. SÃO PAULO, TJ-SP, CC. n. 0255694-53.2012.8.26.0000, São Paulo, Turma Especial de Direito Público, rel. des. Octavio Machado de Barros, j. 09.08.2013.

210. SÃO PAULO, TJ-SP, CC. n. 0122387-66.2013.8.26.0000, Monte Alto, Turma Especial de Direito Público, rel. des. Sidney Romano dos Reis, j. 23.08.2013.

211. SÃO PAULO, TJ-SP, CC. n. 0190404-57.2013.8.26.0000, São Paulo, Turma Especial de Direito Público, rel. des. Cyro Bonilha, j. 29.11.2013.

212. SÃO PAULO, TJ-SP, EDcl. n. 0028555-95.2008.8.26.0309/50000, Jundiaí, $7^{\mathrm{a}}$ Câmara de Direito Público, rel. des. Moacir Peres, j. 25.03.2013.

213. SÃO PAULO, TJ-SP, EDcl. n. 0206058-60.2008.8.26.0000/50002, São Paulo, 9a Câmara de Direito Público, rel. des. Moreira de Carvalho, j. 21.08.2013.

214. SÃO PAULO, TJ-SP, Ação Rescisória n. 0035146-54.2013.8.26.0000, Mairinque, $3^{\circ}$ Grupo de Direito Privado, rel. des. Percival Nogueira, j. 04.12.2013.

215. SÃO PAULO, TJ-SP, Agl. n. 0146399-47.2013.8.26.0000, São Paulo, ga Câmara de Direito Público, rel. des. Oswaldo Luiz Palu, j. 28.01.2014.

216. SÃO PAULO, TJ-SP, Agl. n. 2017430-43.2014.8.26.0000, Ribeirão Preto, $26^{a}$ Câmara de Direito Privado, rel. des. Felipe Ferreira, j. 12.03.2014.

217. SÃO PAULO, TJ-SP, Agl. n. 0144871-75.2013.8.26.0000, Sorocaba, 29a Câmara de Direito Privado, rel. des. S. Oscar Feltrin, j. 19.03.2014.

218. SÃO PAULO, TJ-SP, Agl. n. 0051436-47.2013.8.26.0000, São Sebastião, $2^{a}$ Câmara Reservada ao Meio Ambiente, rel. des. Paulo Ayrosa, j. 05.06.2014.

219. SÃO PAULO, TJ-SP, AgRg. n. 2103043-31.2014.8.26.0000/50000, Ribeirão Preto, $10^{a}$ Câmara de Direito Público, rel. des. Teresa Ramos 
Marques, j. 18.08.2014.

220. SÃO PAULO, TJ-SP, AgRg. n. 2085613-66.2014.8.26.0000/50002, Ribeirão Preto, $10^{a}$ Câmara de Direito Público, rel. des. Teresa Ramos Marques, j. 15.09.2014.

221. SÃO PAULO, TJ-SP, AgRg. n. 2130443-20.2014.8.26.0000/50000, Ribeirão Preto, $9^{a}$ Câmara de Direito Privado, rel. des. Mauro Conti Machado, j. 07.10 .2014 .

222. SÃO PAULO, TJ-SP, AgRg. n. 2132965-20.2014.8.26.0000/50000, Ribeirão Preto, $7^{a}$ Câmara de Direito Privado, rel. des. Luis Mario Galbetti, j. 22.10.2014.

223. SÃO PAULO, TJ-SP, AgRg. n. 2132965-20.2014.8.26.0000/50001, Ribeirão Preto, $7^{a}$ Câmara de Direito Privado, rel. des. Luis Mario Galbetti, j. 22.10.2014.

224. SÃO PAULO, TJ-SP, Agravo n. 2085613-66.2014.8.26.0000/50000, Ribeirão Preto, 10 ${ }^{a}$ Câmara de Direito Privado, rel. des. Teresa Ramos Marques, j. 10.08.2014.

225. SÃO PAULO, TJ-SP, Agravo n. 2026006-25.2014.8.26.0000/50000, Ribeirão Preto, $10^{a}$ Câmara de Direito Público, rel. designado p/ acórdão des. Paulo Galizia, j. 29.09.2014.

226. SÃO PAULO, TJ-SP, Apl. n. 0002239-37.2011.8.26.0116, Campos do Jordão, $12^{a}$ Câmara de Direito Público, rel. des. Venicio Salles, j. 22.01.2014.

227. SÃO PAULO, TJ-SP, Apl. n. 0025739-73.2011.8.26.0071, Bauru, $8^{\mathrm{a}}$ Câmara de Direito Público, rel. des. João Carlos Garcia, j. 29.01.2014.

228. SÃO PAULO, TJ-SP, Apl. n. 0007893-76.2012.8.26.0566, São Carlos, $6^{a}$ Câmara de Direito Público, rel. des. Silvia Meirelles, j. 03.02.2014.

229. SÃO PAULO, TJ-SP, Apl. n. 0004038-23.2005.8.26.0053, São Paulo, $4^{a}$ Câmara de Direito Público, rel. des. Ana Luiza Liarte, j. 10.02.2014.

230. SÃO PAULO, TJ-SP, Apl. n. 0017225-63.2011.8.26.0223, Guarulhos, $7^{\text {a }}$ 
Câmara de Direito Privado, rel. des. Mendes Pereira, j. 12.02.2014.

231. SÃO PAULO, TJ-SP, Apl. n. 0002638-89.2010.8.26.0152, Cotia, $2^{\mathrm{a}}$ Câmara de Direito Privado, rel. des. Flavio Abramovici, j. 23.02.2014.

232. SÃO PAULO, TJ-SP, Apl. n. 0045693-95.2010.8.26.0506, Ribeirão Preto, 9a Câmara de Direito Privado, rel. des. Piva Rodrigues, j. 25.02.2014.

233. SÃO PAULO, TJ-SP, Apl. n. 9061266-20.2009.8.26.0000, São Paulo, 9a Câmara de Direito Privado, rel. des. Antonio Vilenilson, j. 08.04.2014.

234. SÃO PAULO, TJ-SP, Apl. n. 0002691-44.2009.8.26.0075, Santos, $2^{\mathrm{a}}$ Câmara de Direito Privado, rel. des. Guilherme Santini Teodoro, j. 06.05.2014.

235. SÃOPAULO, TJ-SP, Apl. n. 0000920-97.2009.8.26.0053, São Paulo, $1^{a}$ Câmara de Direito Privado, rel. des. Vicente de Abreu Amadei, j. 13.05.2014.

236. SÃO PAULO, TJ-SP, Apl. n. 0022509-60.2003.8.26.0602, Sorocaba, $1^{a}$ Câmara de Direito Privado, rel. des. Alcides Leopoldo e Silva Júnior, j. 26.08.2014.

237. SÃO PAULO, TJ-SP, Apl. n. 0017145-44.2010.8.26.0576, São José do Rio Preto, $2^{a}$ Câmara de Direito Privado, rel. des. Giffoni Ferreira, j. 19.08.2014.

238. SÃO PAULO, TJ-SP, Apl. n. 0000633-46.2011.8.26.0189, Fernandópolis, 9a Câmara de Direito Público, rel. des. Rebouças de Carvalho, j. 04.06.2014.

239. SÃO PAULO, TJ-SP, Apl. n. 4003005-61.2013.8.26.0048, Atibaia, $6^{a}$ Câmara de Direito Privado, rel. des. Leme de Campos, j. 16.06.2014.

240. SÃO PAULO, TJ-SP, Apl. e Reexame Necessário n. 00287346.2010.8.26.0220, Guaratinguetá, $2^{a}$ Câmara de Direito Público, rel. des. José Luiz Germano, j. 01.07.2014.

241. SÃO PAULO, TJ-SP, Apl. n. 0004227-02.2000.8.26.0659, Vinhedo, $1^{\mathrm{a}}$ Câmara de Direito Privado, rel. des. Alcides Leopoldo e Silva Júnior, j. 26.08.2014.

242. SÃO PAULO, TJ-SP, Apl. e Reexame Necessário n. 0126263- 
74.2007.8.26.0053, São Paulo, 6ª Câmara de Direito Público, rel. des. Leme de Campos, j. 15.9.2014.

243. SÃO PAULO, TJ-SP, Apl. n. 0018975-41.2011.8.26.0566, São Carlos, 9a Câmara de Direito Privado, rel. des. José Aparício Coelho Prado Neto, j. 16.09.2014.

244. SÃO PAULO, TJ-SP, Apl. n. 0025758-79.2012.8.26.0577, São José dos Campos, $2^{a}$ Câmara Reservada ao Meio Ambiente, rel. des. Paulo Ayrosa, j. 18.09.2014.

245. SÃO PAULO, TJ-SP, Apl. n. 0031515-27.2008.8.26.0114, Campinas, $4^{a}$ Câmara Extraordinária de Direito Privado, rel. des. Luiz Ambra, j. 30.09.2014.

246. SÃO PAULO, TJ-SP, Apl. n. 9000004-83.2012.8.26.0220, Guaratinguetá, $1^{\text {a }}$ Câmara de Direito Público, rel. des. Vicente Abreu Amadei, j. 07.10.2014.

247. SÃO PAULO, TJ-SP, Apl. n. 0002711-85.2006.8.26.0642, Ubatuba, 29a Câmara de Direito Privado, rel. des. Hamid Bdine, j. 08.10.2014.

248. SÃO PAULO, TJ-SP, Apl. n. 0000664-36.2012.8.26.0414, Palmeira D'Oeste, $4^{\text {a }}$ Câmara de Direito Privado, rel. des. Milton Carvalho, j. 30.10.2014.

249. SÃO PAULO, TJ-SP, Apl. n. 1019067-71.2013.8.26.0100, São Paulo, $6^{\mathrm{a}}$ Câmara de Direito Privado, rel. des. Percival Nogueira, j. 04.11.2014.

250. SÃO PAULO, TJ-SP, Apl. n. 0191058-20.2008.8.26.0000, São Paulo, $1^{\text {a }}$ Câmara de Direito Público, rel. des. Vicente de Abreu Amadei, j. 04.11.2014.

251. SÃO PAULO, TJ-SP, Apl. n. 0014668-54.2009.8.26.0068, Barueri, $4^{\mathrm{a}}$ Câmara Extraordinária de Direito Privado, rel. des. Silvério da Silva, j. 29.10.2014.

252. SÃO PAULO, TJ-SP, Apl. n. 0022575-74.2010.8.26.0576, São José do Rio Preto, $6^{\mathrm{a}}$ Câmara de Direito Privado, rel. des. Fortes Barbosa, j. 13.11.2014.

253. SÃO PAULO, TJ-SP, Apl. n. 0014766-18.2011.8.26.0602, Sorocaba, $7^{\text {a }}$ Câmara de Direito Privado, rel. des. Miguel Brandi, j. 11.12.2014. 
254. SÃO PAULO, TJ-SP, Arguição de Inconstitucionalidade n. 005561927.2014.8.26.0000, Atibaia, 6 ${ }^{a}$ Câmara de Direito Público, rel. des. Arantes Theodoro, j. 03.12.2014.

255. SÃO PAULO, TJ-SP, Apl. e Reexame Necessário n. 090124121.2000.8.26.0022, Guaratinguetá, $2^{\mathrm{a}}$ Câmara de Direito Público, rel. des. José Luiz Germano, j. 01.07.2014.

256. SÃO PAULO, TJ-SP, Apl. n. 0040813-07.2011.8.26.0577, São José dos Campos, $13^{\text {a }}$ Câmara de Direito Público, rel. des. Borelli Thomaz, j. 17.09.2014.

257. SÃO PAULO, TJ-SP, Apl. n. 0073965-15.2012.8.26.0576, São José do Rio Preto, $7^{\text {a }}$ Câmara de Direito Privado, rel. des. Miguel Brandi, j. 28.08.2014.

258. SÃO PAULO, TJ-SP, Apl. n. 0165744-43.2006.8.26.0000, São Paulo, $1^{\text {a }}$ Câmara de Direito Público, rel. des. Vicente de Abreu Amadei, j. 04.11.2014.

259. SÃO PAULO, TJ-SP, Apl. n. 9206717-76.2009.8.26.0000, Ubatuba, $5^{\text {a }}$ Câmara Extraordinária de Direito Privado, rel. des. Natan Zelinschi de Arruda, j. 25.06.2014.

260. SÃO PAULO, TJ-SP, Apl. n. 0031147-70.2009.8.26.0053, São Paulo, $1^{\text {a }}$ Câmara de Direito Público, rel. des. Vicente de Abreu Amadei, j. 13.05.2014.

261. SÃO PAULO, TJ-SP, CC. n. 0208436-13.2013.8.26.0000, Lins, Turma Especial de Direito Público, rel. des. Venicio Salles, j. 21.02.2014.

262. SÃO PAULO, TJ-SP, Apl. n. 0014649-03.2006.8.26.0602, Sorocaba, $3^{\text {a }}$ Câmara Extraordinária de Direito Privado, rel. des. Ruy Coppola, j. 24.04.2014.

263. SÃO PAULO, TJ-SP, Apl. n. 0614460-03.2008.8.26.0053, São Paulo, $1^{\text {a }}$ Câmara Reservada ao Meio Ambiente, rel. des. João Negrini Filho, j. 23.01.2014.

264. SÃO PAULO, TJ-SP, CC. n. 0026834-55.2014.8.26.0000, São José do Rio Preto, $6^{a}$ Câmara de Direito Público, rel. des. Rebouças de Carvalho, j. 09.05.2014.

265. SÃO PAULO, TJ-SP, CC. n. 0185261-87.2013.8.26.0000, Cachoeira 
Paulista, Turma Especial de Direito Público, rel. des. Souza Nery, j. 28.03.2014. 266. SÃO PAULO, TJ-SP, CC. n. 0000040-94.2014.8.26.0000, Monte Alto, Turma Especial de Direito Público, rel. des. Paulo Barcellos Gatti, j. 29.08.2014. 267. SÃO PAULO, TJ-SP, CC. n. 2143065-34.2014.8.26.0000, São Paulo, Órgão Especial, rel. des. Luiz Ambra, 12.11.2014.

268. SÃO PAULO, TJ-SP, EDcl. n. 0146399-47.2013.8.26.0000/50000, São Paulo, 9a Câmara de Direito Público, rel. des. Oswaldo Luiz Palu, j. 09.04.2014. 269. SÃO PAULO, TJ-SP, EDcl. n. 0005580-63.2011.8.26.0248/50000, Indaiatuba, 9a Câmara de Direito Privado, rel. des. Alexandre Lazzarini, j. 03.06.2014.

270. SÃO PAULO, TJ-SP, EDcl. n. 0002691-44.2009.8.26.0075/50000, Santos, $2^{\mathrm{a}}$ Câmara de Direito Privado, rel. des. Guilherme Santini Teodoro, j. 05.08.2014.

271. SÃO PAULO, TJ-SP, EDcl. n. 2085613-66.2014.8.26.0000/50003, Ribeirão Preto, $10^{\mathrm{a}}$ Câmara de Direito Privado, rel. des. Teresa Ramos Marques, j. 10.11.2014.

272. SÃO PAULO, TJ-SP, Ação Rescisória n. 0013719-35.2012.8.26.0000, Avaré, $6^{\circ}$ Grupo de Direito Público, rel. des. Edson Ferreira da Silva, j. 16.07.2014.

273. SÃO PAULO, TJ-SP, Agl. n. 0099203-18.2012.8.26.0000, Atibaia, 2a Câmara Reservada ao Meio Ambiente, rel. des. Paulo Ayrosa, j. 05.02.2015.

274. SÃO PAULO, TJ-SP, Agl. n. 2175552-57.2014.8.26.0000, Ribeirão Preto, $9^{a}$ Câmara de Direito Privado, rel. des. Mauro Conti Machado, j. 03.02.2015.

275. SÃO PAULO, TJ-SP, Agl. n. 2100145-45.2014.8.26.0000, Americana, $12^{\mathrm{a}}$ Câmara de Direito Público, rel. des. Osvaldo de Oliveira, j. 18.03.2015.

276. SÃO PAULO, TJ-SP, Agl. n. 2117694-68.2014.8.26.0000, Americana, $12^{\mathrm{a}}$ Câmara de Direito Público, rel. des. Osvaldo de Oliveira, j. 08.04.2015. 
277. SÃO PAULO, TJ-SP, Agl. n. 2127790-45.2014.8.26.0000, Americana, $12^{\mathrm{a}}$ Câmara de Direito Público, rel. des. Osvaldo de Oliveira, j. 08.04.2015.

278. SÃO PAULO, TJ-SP, Agl. n. 2007940-60.2015.8.26.0000, Ribeirão Preto, $2^{\text {a }}$ Câmara Reservada ao Meio Ambiente, rel. des. Paulo Ayrosa, j. 16.04.2015.

279. SÃO PAULO, TJ-SP, Agl. n. 2098934-71.2014.8.26.0000, Americana, $12^{\mathrm{a}}$ Câmara de Direito Público, rel. des. Osvaldo de Oliveira, j. 10.06.2015.

280. SÃO PAULO, TJ-SP, Agl. n. 2019415-13.2015.8.26.0000, Americana, $12^{\mathrm{a}}$ Câmara de Direito Público, rel. des. Osvaldo de Oliveira, j. 29.07.2015.

281. SÃO PAULO, TJ-SP, Agl. n. 2103952-39.2015.8.26.0000, Ribeirão Preto, $4^{\text {a }}$ Câmara de Direito Privado, rel. des. Fábio Quadros, j. 30.07.2015.

282. SÃO PAULO, TJ-SP, Agl. n. 2104522-25.2015.8.26.0000, Ribeirão Preto, $4^{\text {a }}$ Câmara de Direito Privado, rel. des. Fábio Quadros, j. 30.07.2015.

283. SÃO PAULO, TJ-SP, Agl. n. 2019015-96.2015.8.26.0000, Americana, $12^{\text {a }}$ Câmara de Direito Público, rel. des. Osvaldo de Oliveira, 19.08.2015.

284. SÃO PAULO, TJ-SP, Agl. n. 2177932-53.2014.8.26.0000, Ribeirão Preto, $8^{\text {a }}$ Câmara de Direito Privado, rel. des. Pedro de Alcântara da Silva Leme Filho, j. 18.09.2015.

285. SÃO PAULO, TJ-SP, Agl. n. 2129242-56.2015.8.26.0000, Santa Isabel, $2^{\text {a }}$ Câmara Reservada ao Meio Ambiente, rel. Paulo Ayrosa, j. 17.09.2015.

286. SÃO PAULO, TJ-SP, Agl. 2106039-02.2014.8.26.0000, Americana, $12^{\text {a }}$ Câmara de Direito Público, rel. des. Osvaldo de Oliveira, j. 16.09.2015.

287. SÃO PAULO, TJ-SP, Agl. n. 2104674-10.2014.8.26.0000, Americana, $12^{\mathrm{a}}$ Câmara de Direito Público, rel. des. Osvaldo de Oliveira, j. 30.09.2015.

288. SÃO PAULO, TJ-SP, Agl. n. 2114054-57.2014.8.26.0000, Americana, $12^{\mathrm{a}}$ Câmara de Direito Público, rel. des. Osvaldo de Oliveira, j. 30.09.2015.

289. SÃO PAULO, TJ-SP, Agl. n. 2124762-69.2014.8.26.0000, Americana, $12^{\text {a }}$ Câmara de Direito Público, rel. des. Osvaldo de Oliveira, j. 30.09.2015. 
290. SÃO PAULO, TJ-SP, Agl. n. 2082924-15.2015.8.26.0000, Cotia, $2^{\mathrm{a}}$ Câmara Reservada ao Meio Ambiente, rel. des. Vera Angrisani, j. 15.10.2015.

291. SÃO PAULO, TJ-SP, Agl. n. 2104522-25.2015.8.26.0000, Ribeirão Preto, $7^{a}$ Câmara de Direito Público, rel. des. Magalhães Coelho, j. 19.10.2015.

292. SÃO PAULO, TJ-SP, Agl. n. 2103942-29.2014.8.26.0000, Americana, $12^{\mathrm{a}}$ Câmara de Direito Público, rel. des. Osvaldo de Oliveira, j. 02.12.2015.

293. SÃO PAULO, TJ-SP, AgRg. n. 0005031-53.2011.8.26.0248/50003, Indaiatuba, Câmara Especial de Presidentes, rel. des. Artur Marques, j. 03.07.2015.

294. SÃO PAULO, TJ-SP, Apl. n. 1066651-03.2014.8.26.0100, São Paulo, Conselho Superior da Magistratura, rel. des. Elliot Akel, j. 30.06.2015.

295. SÃO PAULO, TJ-SP, Apl. n. 0062537-74.2006.8.26.0114, Campinas, $12^{\mathrm{a}}$ Câmara Extraordinária de Direito Privado, rel. des. Dimitrios Zarvos Varellis, j. 30.01.2015.

296. SÃO PAULO, TJ-SP, Apl. n. 0005528-80.2005.8.26.0053, São Paulo, $11^{\text {a }}$ Câmara de Direito Público, rel. des. Oscild de Lima Júnior, j. 03.03.2015.

297. SÃO PAULO, TJ-SP, Apl. n. 0009520-72.2012.8.26.0451, Piracicaba, 29a Câmara de Direito Privado, rel. des. Pereira Calças, j. 11.03.2015.

298. SÃO PAULO, TJ-SP, Apl. n. 0007786-47.2007.8.26.0068, Barueri, $10^{\mathrm{a}}$ Câmara de Direito Privado, rel. des. Carlos Alberto Garbi, j. 07.04.2015.

299. SÃO PAULO, TJ-SP, Apl. n. 0001587-64.2001.8.26.0247, São Sebastião, $12^{\mathrm{a}}$ Câmara Extraordinária de Direito Privado, rel. des. Dimitrios Zarvos Varellis, j. 08.05.2015.

300. SÃO PAULO, TJ-SP, Apl. n. 0115669-59.2009.8.26.0011, São Paulo, 36 Câmara de Direito Privado, rel. des. Jayme Queiroz Lopes, j. 28.05.2015.

301. SÃO PAULO, TJ-SP, Apl. n. 4003005-61.2013.8.26.0048, Atibaia, $6^{\text {a }}$ Câmara de Direito Público, rel. des. Leme de Campos, j. 01.06.015. 
302. SÃO PAULO, TJ-SP, Apl. n. 0026215-72.2010.8.26.0451, Piracicaba, $28^{\mathrm{a}}$ Câmara de Direito Privado, rel. des. Mario Chiuvite Junior, j. 16.06.2015.

303. SÃO PAULO, TJ-SP, Apl. n. 1013527-81.2014.8.26.0011, São Paulo, $6^{\text {a }}$ Câmara de Direito Privado, rel. des. Fortes Barbosa, j. 19.06.2015.

304. SÃO PAULO, TJ-SP, Apl. n. 0008306-64.2008.8.26.0361, Mogi das Cruzes, $2^{\mathrm{a}}$ Câmara Reservada ao Meio Ambiente, rel. des. Paulo Ayrosa, j. 18.06.2015.

305. SÃO PAULO, TJ-SP, Apl. n. 0012002-61.2001.8.26.0068, Barueri, 10 Câmara de Direito Privado, rel. des. Carlos Alberto Garbi, j. 23.06.2015.

306. SÃO PAULO, TJ-SP, Apl. n. 0019225-15.2009.8.26.0576, São José do Rio Preto, $13^{\mathrm{a}}$ Câmara de Direito Privado, rel. des. Grava Brazil, j. 07.07.2015.

307. SÃO PAULO, TJ-SP, Apl. n. 1006287-64.2014.8.26.0068, Barueri, 9a Câmara de Direito Público, rel. des. Rebouças de Carvalho, j. 29.07.2015.

308. SÃO PAULO, TJ-SP, Apl. n. 1009527-43.2013.8.26.0053, São Paulo, $4^{\text {a }}$ Câmara de Direito Público, rel. des. Luis Fernando Camargo de Barros Vidal, j. 03.08.2015.

309. SÃO PAULO, TJ-SP, Apl. n. 4006526-18.2013.8.26.0564, São Bernardo do Campo, $31^{\text {a }}$ Câmara de Direito Privado, rel. des. Francisco Casconi, j. 04.08.2015.

310. SÃO PAULO, TJ-SP, Apl. n. 0003218-73.2013.8.26.0101, Caçapava, $2^{\text {a }}$ Câmara de Direito Público, rel. des. José Luiz Germano, j. 28.07.2015.

311. SÃO PAULO, TJ-SP, Apl. n. 9161826-04.2008.8.26.0000, São José do Rio Preto, $5^{\text {a }}$ Câmara Extraordinária de Direito Público, rel. des. Rebouças de Carvalho, j. 19.08.2015.

312. SÃO PAULO, TJ-SP, Apl. n. 4000108-92.2013.8.26.0587, São Sebastião, $3^{\text {a }}$ Câmara de Direito Privado, rel. des. Alexandre Marcondes, j. 26.08.2015.

313. SÃO PAULO, TJ-SP, Apl. n. 0008622-75.2001.8.26.0053, São Paulo, $1^{\text {a }}$ 
Câmara de Direito Público, rel. des. Marcos Pimentel Tamassia, j. 08.09.2015.

314. SÃO PAULO, TJ-SP, Apl. n. 0007991-44.2012.8.26.0022, Amparo, $2^{\mathrm{a}}$ Câmara de Direito Público, rel. des. José Luiz Germano, j. 01.09.2015.

315. SÃO PAULO, TJ-SP, Apl. e Reexame Necessário n. 000961748.2008.8.26.0666, Mogi-Mirim, $2^{\mathrm{a}}$ Câmara Reservada ao Meio Ambiente, rel. des. Paulo Ayrosa, j. 17.09.2015.

316. SÃO PAULO, TJ-SP, Apl. e Reexame Necessário n. 001221016.2009.8.26.0278, Itaquaquecetube, $2^{\mathrm{a}}$ Câmara Reservada ao Meio Ambiente, rel. des. Paulo Ayrosa, rel. 15.10.2015.

317. SÃO PAULO, TJ-SP, Apl. n. 0000055-66.2005.8.26.0004, São Paulo, $18^{a}$ Câmara Extraordinária de Direito Privado, rel. des. Arantes Theodoro, j. 26.10.2015.

318. SÃO PAULO, TJ-SP, Apl. n. 0201116-68.2011.8.26.0100, São Paulo, 29a Câmara de Direito Privado, rel. des. Pereira Calças, j. 11.11.2015.

319. SÃO PAULO, TJ-SP, Apl. e Reexame Necessário n. 101518303.2014.8.26.0196, Franca, 12ª Câmara de Direito Público, Venicio Salles j. 04.11 .2015$.

320. SÃO PAULO, TJ-SP, Apl. n. 0605255-47.2008.8.26.0053, São Paulo, $12^{\mathrm{a}}$ Câmara de Direito Público, rel. des. Osvaldo de Oliveira, j. 14.12.2015.

321. SÃO PAULO, TJ-SP, Apl. n. 4001986-30.2013.8.26.0077, Birigui, $3^{a}$ Câmara de Direito Privado, rel. des. Egidio Giacoia, j. 15.12.2015.

322. SÃO PAULO, TJ-SP, Apl. n. 1006202-93.2014.8.26.0451, Piracicaba, $12^{a}$ Câmara de Direito Público, rel. des. Isabel Cogan, j. 29.05.2015.

323. SÃO PAULO, TJ-SP, EDcl. n. 0165744-43.2006.8.26.0000/50004, São Paulo, $1^{\text {a }}$ Câmara de Direito Público, rel. des. Vicente de Abreu Amadei, j. 10.02.2015.

324. SÃO PAULO, TJ-SP, EDcl. 2026006-25.2014.8.26.0000/50003, Ribeirão 
Preto, 10ª Câmara de Direito Público, rel. des. Paulo Galizia, j. 09.05.2015.

325. SÃO PAULO, TJ-SP, EDcl. n. 2132965-20.2014.8.26.0000/50002, Ribeirão Preto, $7^{\text {a }}$ Câmara de Direito Privado, rel. des. Luis Mario Galbetti, j. 25.02.2015.

326. SÃO PAULO, TJ-SP, EDcl. n. 2026006-25.2014.8.26.0000/50004, Ribeirão Preto, $10^{\mathrm{a}}$ Câmara de Direito Público, rel. des. Paulo Galizia, j. 27.04.2015.

327. SÃO PAULO, TJ-SP, EDcl. n. 0010868-55.2012.8.26.0248/50000, Indaiatuba, $1^{\text {a }}$ Câmara de Direito Privado, rel. des. Alcides Leopoldo e Silva Júnior, j. 23.06.2015.

328. SÃO PAULO, TJ-SP, EDcl. n. 2097980-88.2015.8.26.0000/50000, Ribeirão Preto, $4^{\mathrm{a}}$ Câmara de Direito Privado, rel. des. Fábio Quadros, j. 05.11.2015.

329. SÃO PAULO, TJ-SP, El. n. 0037172-45.2010.8.26.0577/50000, São José do Rio Preto, $5^{\mathrm{a}}$ Câmara de Direito Público, rel. des. Fermino Magnani Filho, j. 27.03.2015.

330. SÃO PAULO, TJ-SP, El. n. 0941102-94.2012.8.26.0506/50000, Ribeirão Preto, $1^{\text {a }}$ Câmara de Direito Privado, rel. des. Luiz Antonio de Godoy, j. 18.08.2015.

331. SÃO PAULO, TJ-SP, Apl. n. 212.726-1/8, São Paulo, $8^{a}$ Câmara Civil, rel. des. José Osório, j. 16.12.1994.

332. SÃO PAULO, TJ-SP, Apl. n. 1001334-11.2018.8.26.0426, Patrocínio Paulista, $5^{\mathrm{a}}$ Câmara de Direito Privado, rel. des. James Siano, j. 25.11.2019. 


\section{WEBSITES CONSULTADOS:}

CIA. CITY. Endereço: <http://www.ciacity.com.br/>. Acesso em: 04.01.2020.

FUNDAÇÃO SISTEMA ESTADUAL DE ANÁLISE DE DADOS DO ESTADO DE SÃO PAULO. Endereço: <http://www.imp.seade.gov.br/>. Acesso em: 07.01.2020.

GEOSAMPA.

Endereço: $<$ http://geosampa.prefeitura.sp.gov.br/PaginasPublicas/_SBC.aspx\#>. Acesso em: 04.01.2020.

PREFEITURA DE SÃO PAULO. Endereço: <http://www.capital.sp.gov.br/>. Acesso em: 06.01.2020.

RED BARN VILLAGE. Endereço: <https://www.nviz.biz/red-barn-village.html>. Acesso em: 04.01.2020.

SECRETARIA DE DESENVOLVIMENTO SOCIAL DO ESTADO DE SÃO PAULO. Endereço: <http://www.desenvolvimentosocial.sp.gov.br/>. Acesso em: 07.01.2020. 